\title{
Chronic Obstructive Pulmonary Disease and Lung Cancer: New Molecular Insights
}

\author{
Ian M. Adcock ${ }^{a}$ Gaetano Caramorib Peter J. Barnes ${ }^{a}$ \\ ${ }^{a}$ Airways Disease Section, National Heart and Lung Institute, Imperial College London, London, UK; \\ ${ }^{b}$ Section of Respiratory Disease, University of Ferrara, Ferrara, Italy
}

\section{Key Words}

Chronic obstructive pulmonary disease $\cdot$ Non-small cell lung carcinoma $\cdot$ Smoking $\cdot$ Oxidative stress $\cdot$ Inflammation • Kinase pathways

\begin{abstract}
Both chronic obstructive pulmonary disease (COPD) and lung cancer are major causes of death worldwide. In most cases this reflects cigarette smoke exposure which is able to induce an inflammatory response in the airways of smokers. Indeed, COPD is characterized by lower airway inflamma-tion, and importantly, the presence of COPD is by far the greatest risk factor for lung cancer amongst smokers. Cigarette smoke induces the release of many inflammatory mediators and growth factors including TGF- $\beta$, EGFR, IL-1, IL-8 and G-CSF through oxidative stress pathways and this inflammation may persist for decades after smoking cessation. Mucus production is also increased by these inflammatory mediators, further linking airway inflammation to an important mechanism of lung cancer. A greater understanding of the molecular and cellular pathobiology that distinguishes smokers with lung cancer from smokers with and without COPD is needed to unravel the complex molecular interactions between COPD and lung cancer. By understanding the common signalling pathways involved in COPD and lung cancer the hope is that treatments will be developed that not only treat the underlying disease process in COPD, but also reduce the currently high risk of developing lung cancer in these patients.
\end{abstract}

Copyright $\odot 2011$ S. Karger AG, Basel

\section{KARGER}

Fax +4161306 1234

E-Mail karger@karger.ch

www.karger.com (c) 2011 S. Karger AG, Basel

0025-7931/11/0814-0265\$38.00/0

Accessible online at:

www.karger.com/res

\section{Introduction}

Chronic obstructive pulmonary disease (COPD) has been described as a 'preventable and treatable disease with some significant extrapulmonary effects that may contribute to the severity in individual patients. Its pulmonary component is characterized by airflow limitation that is not fully reversible. The airflow limitation is usually progressive and associated with an abnormal inflammatory response of the lung to noxious particles or gases' [1]. COPD prevalence, morbidity and mortality vary and are directly related to the prevalence of tobacco smoking except in developing countries where air pollution resulting from the burning of biomass fuels is also important $[1,2]$. COPD is currently a leading cause of morbidity and mortality worldwide whose prevalence and burden are projected to increase due to smoke exposure and the changing age structure of the world population, particularly in women $[1,3]$. COPD is characterized by a chronic inflammation of the lower airway and, importantly, the presence of COPD increases the risk of lung cancer up to 4.5-fold among long-term smokers [4-9]. COPD is by far the greatest risk factor for lung cancer amongst smokers and is found in $50-90 \%$ of patients with

Previous article in this series: Rooney $C$, Sethi T: The epithelial cell and lung cancer: the link between chronic obstructive pulmonary disease and lung cancer. Respiration 2011;81:89-104. 
lung cancer [10]. Even a small reduction in forced expiratory volume in $1 \mathrm{~s}\left(\mathrm{FEV}_{1}\right)$, a marker of airflow obstruction, is a significant predictor of lung cancer, especially among women [11]. There is a racial effect as the risk of lung cancer increases significantly for white women but not in African-American women possibly due to racial admixing $[12,13]$.

Lung cancer accounts for $12 \%$ of all cancers diagnosed worldwide, making it the most common malignancy other than non-melanoma skin cancer and approximately and over one million die of lung cancer each year [14]. Worldwide, tobacco smoking is associated with more of $90 \%$ of cases of lung cancer [15]. In more developed countries, the incidence and mortality rates are generally declining, reflecting previous trends in smoking prevalence. However, in less developed countries lung cancer rates are predicted to continue to increase due to endemic tobacco use [16]. There is a clear role for genetics since only $15 \%$ of lifetime smokers develop lung cancer and $10 \%$ of lung cancers occur in never-smokers especially in women [17] and in Asiatic women in particular [18].

In addition, lung cancer is also a leading cause of morbidity and mortality in patients with COPD as 33\% of patients died of lung cancer over a 14.5-year follow-up [19]. Furthermore $50-70 \%$ of patients diagnosed with lung cancer have spirometric evidence of COPD [20]. Non-small cell lung carcinoma (NSCLC) accounts for $85 \%$ of all lung cancer cases in the United States [21] and importantly, the COPD-related cancer type (squamous cell carcinoma) [22] still represents the most common histological subtype of lung cancer in European men [23]. Despite significant advances in diagnosis and mechanistic understanding of the pathophysiology of lung cancer there has been little improvement in 5-year survival rates $(\sim 15 \%$ overall and $<14 \%$ among males and $<18 \%$ among females), indicating that new approaches are needed [16, 24, 25].

Thus, the environmental risk factor cigarette smoke exposure in combination with a genetic predisposition results in two of the leading causes of morbidity and mortality worldwide namely lung cancer and COPD. Importantly, the risk of both diseases is increasing disproportionately in women [7]. They may, therefore, share similar pathogenic mechanisms (fig. 1).

\section{Inflammation in COPD}

Cigarette smokers develop some degree of lung inflammation, but the COPD patient develops a greater degree of inflammation that progresses with advanced dis- ease [26], often accompanied by systemic inflammation and by increased inflammation in the heart, blood vessels and skeletal muscle [27]. Squamous cell metaplasia and cell atypia are features of cigarette smokers, and these changes may be precursors of cancer development; on the other hand, apoptosis is one potential mechanism for alveolar destruction. Breakdown of extracellular matrix in parenchymal tissues and an increase in extracellular matrix production in the adjacent small airways occur simultaneously, determined by the microenvironment. Oxidative stress provided by exogenous cigarette smoke itself and from endogenous cellular sources may lead to the activation of many intracellular pathways including kinases, transcription factors and epigenetic events that modulate the inflammatory response and cell cycling/ proliferation [27].

The chronic inflammation of COPD is characterized by an accumulation of neutrophils, macrophages, B cells, lymphoid aggregates and CD4+ and CD8+ T cells particularly in the small airways [28] and the degree of inflammation increases with the disease severity as classified by the Global Initiative for Chronic Obstructive Lung Disease (GOLD) [26]. Neutrophils and activated macrophages release oxygen radicals, elastase, and cytokines that are essential to the pathogenesis of COPD, with effects on goblet cells and submucosal glands, and on the induction of emphysema and inflammation. Monocytes/ macrophages are important effector cells in COPD due to the release of reactive oxygen species, extracellular matrix proteins, lipid mediators, cytokines, chemokines and matrix metalloproteinases [29] and their numbers increase with increasing severity [26]. Cigarette smoke extract impairs the phagocytic ability of both neutrophils and macrophages and these abnormalities may underlie the increased risk of respiratory infections in smokers and in COPD patients [27, 30].

An increased number of eosinophils and eosinophil products such as eosinophil cationic protein have been reported in sputum, bronchoalveolar lavage fluid and in the airway wall [31-35]. The role of eosinophils in pathogenesis of COPD is unclear but patients with increased numbers of sputum and bronchoalveolar lavage eosinophils may represent a distinct subgroup of COPD who have concurrent asthma and respond to corticosteroid treatment [36-38].

CD8+ T cells are increased throughout the airways and in lung parenchyma [39] but their role still remains speculative although one role for CD8 T cells is to remove virally infected cells by cytolysis or apoptosis [27]. 
Fig. 1. The major inducer of both lung cancer and COPD is cigarette smoke, although non-smokers may also develop these diseases due to other environmental factors and/or a subject's specific genetic or epigenetic background. Cigarette smoke induces an inflammatory response and increases the numbers of reactive oxygen species (ROS) in the lung. Normal subjects can overcome these stressors, whereas susceptible subjects will develop the pathophysiological changes associated with COPD and/or lung cancer. A combination of immune-inflammatory signals and epigenetic events may underlie the enhanced risk of patients with COPD developing lung cancer.

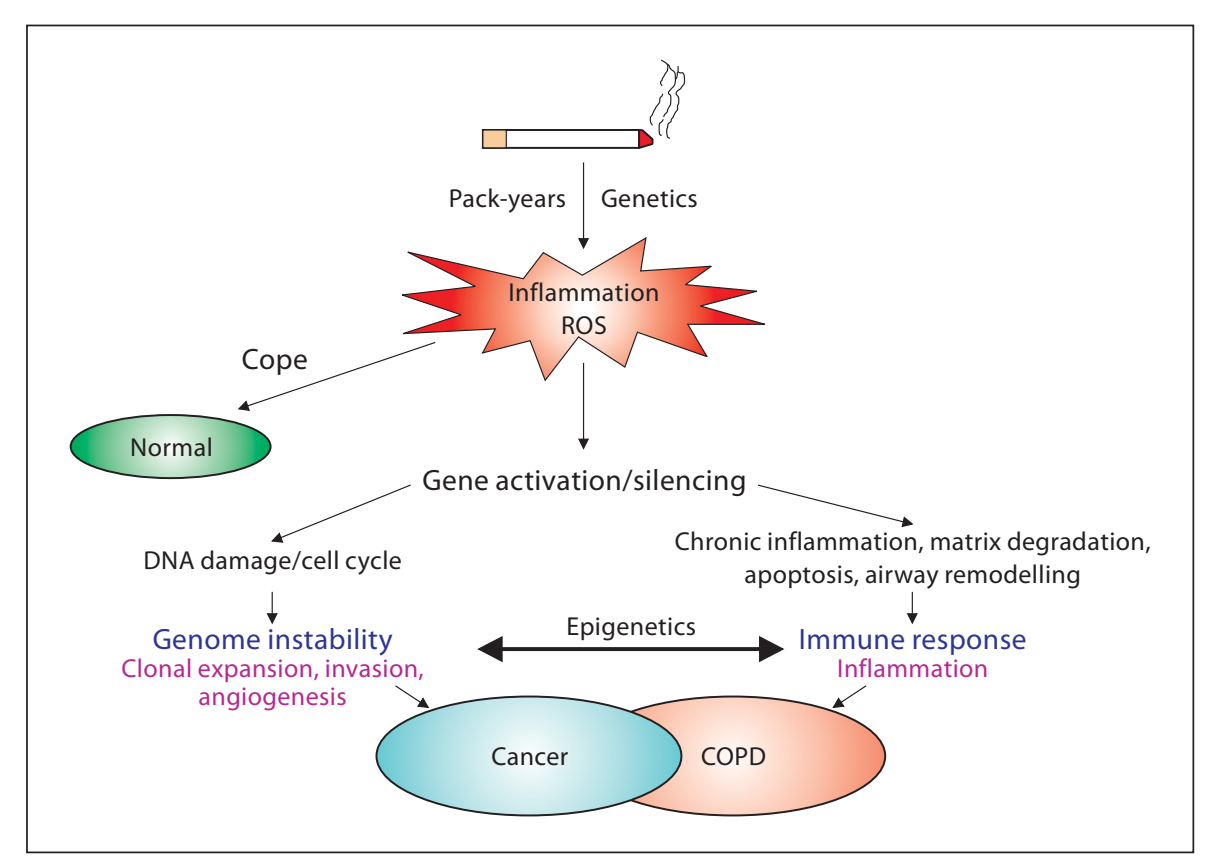

Lymphoid follicles consisting of B cells and follicular dendritic cells with adjacent $\mathrm{T}$ cells were demonstrated both in the parenchyma and in bronchial walls of patients with emphysema [40]. The B cell increase may also reflect a role for autoimmune responses, and this is supported by the reduced numbers of $\mathrm{T}$ regulatory cells reported in lungs of COPD patients [41]. The accumulation of dendritic cells in the epithelium and adventitia of small airways of patients with COPD with increasing severity [42] supports the involvement of adaptive immunity.

The amount of airway smooth muscle in small airways increases in COPD patients and this is inversely correlated with lung function [27]. Airway smooth muscle can also release a host of inflammatory mediators including cytokines, chemokines, growth factors, and proteases which may be important in the pathogenesis of COPD [27].

Goblet cell hyperplasia is more pronounced in smokers with COPD [43] and chronic sputum production is associated with an increased risk of hospitalization, an excessive yearly decline in $\mathrm{FEV}_{1}$ and the development of COPD [44]. The epithelial response to cigarette smoke may represent attempts by the airway epithelium to protect itself and repair the injury caused by cigarette smoke [45]. Injury may lead to the development of squamous metaplasia, which is the reversible replacement of the columnar epithelium by a squamous epithelium, an effect that was correlated to airflow obstruction [46]. Squamous cell metaplasia impairs mucociliary clearance and contributes to the increased risk of squamous cell carcinoma in COPD [22]. Epithelial cells from smokers show upregulation of pro-apoptotic, antioxidant and ubiquitin proteosome pathways [27]. Furthermore, a proteomic study of cells from chronic smokers indicated the upregulation of several proteins involved in the unfolded protein response which is a compensatory mechanism for the effect of reactive oxygen species on protein folding [47].

Cigarette smoke induces the release of many inflammatory mediators and growth factors including TGF- $\beta$, IL-1, IL-8 and G-CSF through oxidative pathways [27]. Activation of the epithelial growth factor receptor (EGFR) cascade is increased in bronchial biopsies from smokers with or without COPD compared to non-smokers [48, 49], and smoking cessation does not lead to a reduction in EGFR expression [50]. This indicates that chronic cigarette exposure may lead to permanent changes in the epithelium. Overexpression of EGFR has been one of the earliest abnormalities found in smokers at high risk of developing lung cancer [51] and smoking somatic mutations can persist for years once acquired [52, 53]. EGFR activation mediates mucus hypersecretion in response to neutrophil elastase and oxidative stress, thus linking airway inflammation to an important mechanism of lung cancer [54]. 


\section{Stepwise Progression towards Squamous Cell Lung Carcinoma in the COPD Patients}

A stepwise progression from pathological premalignant changes in the epithelium towards basal cell hyperplasia and dysplasia through to squamous cell carcinoma has been well described [55]. It has been postulated that this occurs due to mutations in tumour suppressor genes such as p53 within a single progenitor bronchial epithelial cell which expands to populate broad areas of the bronchial mucosa. This concept is known as field carcinogenesis [56].

Although there is a field effect phenomenon for preneoplastic lung lesions, recent data suggest that there are at least two distinct lung airway compartments involved in lung cancer pathogenesis - central and peripheral. Lower airway inflammation may also play an important role in lung cancer development and could be an important component of the field effect phenomenon [57]. This stepwise progression may be facilitated in smokers who develop COPD due to impaired clearance of carcinogenic substances since enhanced particulate deposition in the major bronchi was modelled to occur in the lungs of patients with COPD [58]. However, the link between COPD and squamous cell lung carcinoma is probably more complex than a simple mechanistic one although the timing of these potential events is unknown.

\section{Pulmonary Stem Cells as a Target of the Carcinogenic Process in Human Squamous Cell Lung Carcinoma}

Evidence suggests a direct relationship between proximal airway basal progenitors and carcinogenesis in murine models of lung cancer although the precise stem cell target of this process in the development of human squamous cell lung carcinoma remains unknown [59]. In murine models a pulmonary stem cell population, termed bronchioalveolar stem cells (BASCs), is found at the bronchoalveolar duct junction. BASCs are resistant to broncholar and alveolar damage and proliferate during epithelial cell renewal in vivo and their transformed counterparts give rise to adenocarcinoma [60-62].

Protein kinase $\mathrm{C}$ iota $(\mathrm{PKC} \mathrm{l})$ is an oncogene required for maintenance of the transformed phenotype of NSCLC cells [63] and in animal models, genetic loss of PKCı dramatically inhibits hyperplasia and subsequent lung tumour formation in vivo. Importantly, this correlates with an inability of PKCı-deficient BASCs to undergo expan- sion and transformation into both squamous cell lung carcinoma and adenocarcinoma [63].

\section{Effect of Smoking on Epithelial Cell Gene Expression Profiles: Links to Lung Cancer and COPD}

The gene expression profile of bronchial epithelial cells from control smokers with normal lung function compared with smokers with COPD has been reported [64-67] and may provide novel clues to the possible links between COPD and squamous cell carcinoma of the lung. Cigarette smoking was associated with increased expression of 175 genes which could be classified into those with xenobiotic functions such as cytochrome P450 (CYP)1B1, antioxidants such as glutathione peroxidase (GPX)2 and aldehyde dehydrogenase (ALDH)3A1, electron transport such as NADPH and putative oncogenes CEACAM6. In contrast, decreased expression of genes involved in regulation of inflammation and several putative tumour suppressor genes (TU3A, SLIT1 and SLIT2, and GAS6) were decreased in smokers. These changes mostly reversed to non-smoker levels with smoking cessation particularly with downregulated genes albeit at different rates [68] except for potential oncogenes and tumour suppressor genes [69]. Importantly, many of these changes in gene expression were associated with changes in protein expression [67]. These later findings may explain the continued risk of developing lung cancer many years after individuals have ceased to smoke.

In addition, genes related to oxidative stress, extracellular matrix synthesis and inflammation were increased in severe emphysema [65]. Using cluster analysis a group of 17 genes was associated with improved outcome following lung volume reduction surgery.

The protein aldo-keto reductase family 1 member B10 (AKR1B10) is overexpressed in the bronchial epithelium of COPD patients and in the neoplastic cells of squamous cell carcinoma of the lung $[64,70]$. Aldo-keto reductases are $\mathrm{NADPH}$-dependent oxidoreductases that catalyze the reduction of a variety of carbonyl compounds [70]. AKR1B10 may also affect cell cycle progression following translocation to the nucleus [70].

\section{Multiple Genes}

Given the heterogeneous nature of lung cancer and COPD, monitoring of only one or a few genes is probably of limited value. A pan-genomic analysis using high- 
throughput gene expression analysis seems more efficient for identifying specific events in lung carcinogenesis and in COPD [71]. Since 2000, several studies have proposed a molecular classification of human lung carcinomas on the basis of gene expression panels and have described numerous putative biological markers of lung cancer [72]. Using a gene microarray on histologically normal largeairway epithelial cells obtained at bronchoscopy from smokers with suspicion of lung cancer, Spira et al. [66] have identified an 80-gene biomarker that distinguishes smokers with and without lung cancer with an accuracy of $83 \%$ ( $80 \%$ sensitive, $84 \%$ specific), and approximately $90 \%$ sensitivity for stage 1 lung cancer. In a similar vein, studies are now being conducted to look at whole genomes from lung cancer cells using deep sequencing technologies [73, 74]. Furthermore, global analysis of epigenetic marks including histone and DNA methylation [75] and micro-RNA (miRNA) profiles [76] are beginning to demonstrate distinct profiles between cancer cell types. The potential for personalized medicine based on precise delineation of an individual's global genomic and epigenomic maps is expensive but may be feasible in the future as the cost of arrays decreases. At this time, improving the biological significance of microarray data is still an important clinical challenge [72]. Similar studies in COPD are required to distinguish these profiles from that of lung cancer.

\section{Genetic and Epigenetic Abnormalities in COPD and Lung Cancer}

Squamous cell lung carcinoma results from the accumulation of multiple independent genetic and epigenetic abnormalities, including DNA sequence alterations, copy number changes, and aberrant promoter hypermethylation [77]. Together, these abnormalities result in the activation of oncogenes and inactivation of tumour suppressor genes [77]. In addition, these abnormalities are often present in premalignant lesions and in histologically normal lung bronchial epithelial cells [77]. Loss of heterozygosity (i.e., deletion of one copy of allelic DNA sequences) and microsatellite alterations in widely dispersed, apparently clonally independent foci $(\sim 90,000$ cells) also occur in normal and hyperplastic bronchial epithelium and these changes may persist for many years after smoking cessation [77].

Familial clustering of COPD occurs particularly in subjects with a severe genetic deficiency of $\alpha_{1}$-antitrypsin who usually develop severe pulmonary emphysema [1].
However, less than $1 \%$ of COPD patients have this deficiency and more recent studies have found some familial aggregation in subjects with COPD even in the absence of pulmonary emphysema $[78,79]$.

There is evidence of familial aggregation of late-onset lung cancer and, even after adjustment for smoking behaviour of probands and their relatives, the risk of lung cancer is still statistically significant. There is no evidence, however, of familial aggregation in early-onset lung cancer or among relatives of Caucasian never-smokers [80] although this may differ depending upon racial background [81]. Using traditional linkage analysis a locus on chromosome 6q23-25 has been associated with both lung cancer [82] and COPD [83].

\section{Oxidative Stress and Xenobiotic Genes}

In both lung cancer and COPD, environmental factors (mainly tobacco smoking) interact with multiple polymorphic genes to influence susceptibility to disease. Thus, only a fraction of smokers (around 15\%) will develop lung cancer and/or COPD in their lifetime $[1,84]$, which suggests a different individual susceptibility to the risk of lung cancer and COPD or time of disease onset. Genes involved in the modulation of oxidant and noxious compounds are likely to be important in gene environment interactions in COPD and lung cancer [12].

Metabolism of noxious substances present in tobacco smoke by xenobiotic metabolizing enzymes is usually benign but in some instances the metabolic process can transform harmless substances into toxic chemicals [5], suggesting that differences in xenobiotic metabolism may contribute to the risk of developing both COPD and squamous cell lung carcinoma $[85,86]$. The major xenobiotic metabolizing enzymes, including both phase I [CYPs, microsomal epoxide hydrolases (EPHX), flavin monooxygenases (such as heme oxygenase-1, HO1) and myeloperoxidase (MPO)] and phase II enzymes [conjugation enzymes, including several transferases such as glutathione S-transferases (GSTs) and arylamine N-acetyltransferases (CoASAc; NAT, EC 2.3.1.5)] are expressed in human lung tissues [87]. Xenobiotics undergo metabolic activation by phase I enzymes, whereas phase II enzymes transform compounds activated by phase I enzymes into inactivated hydrophilic compounds that are eventually excreted [87].

The combination of several genetic polymorphisms in CYPs, EPHX, HO1 and GST enzymes that activate or detoxify the tobacco smoke carcinogens might modulate 
the risk of chronic smokers of developing both COPD and squamous cell lung carcinoma [88]. Polycyclic aromatic hydrocarbons are generally benign but can become toxic following activation by CYP enzymes [5]. Importantly, oestrogen can upregulate the expression of CYP enzymes in lungs and this may account for the sex-related differences in the metabolism of some cigarette smoke constituents in females [5].

The homozygous *2A allele of CYP1A1 is an independent risk factor for very severe COPD [89] whilst the CYP1A1 $\mathrm{m} 1$ homozygous genotype is a risk factor for lung cancer [90]. Two haplotypes in the EPHX1 gene are significantly associated with lung cancer risk in the overall population [86]. The slow- and very-slow-activity phenotypes of EPHX1 are also associated with an increased risk of COPD whereas the fast-activity phenotype of EPHX1 is protective against developing COPD in Asian, but not Caucasian, populations [91]. However, a large Danish study of 47,000 subjects failed to demonstrate any association with EPHX1 variants with an altered risk of COPD although a meta-analysis did not exclude a minor effect [92].

Polymorphisms of $\mathrm{HO} 1$ gene promoter can be grouped into three classes dependent upon the number of GT repeats. Those with large numbers ( $>32$ repeats) have been associated with the development of lung adenocarcinoma in Japanese male smokers [93] and with COPD in a Chinese population [94].

MPO is a lysosomal phase I enzyme expressed predominantly in neutrophil granulocytes, monocytes and macrophages. It activates tobacco smoke-derived carcinogens such as polycyclic aromatic hydrocarbons, benzo(a)pyrene, aromatic and heterocyclic amines and induces the formation of endogenous carcinogenic free radicals [85]. There is a protective effect of the MPO variant allele (i.e. A/A and A/G genotypes) against lung cancer, with the risk reduction of approximately $50 \%$ linked to smoking status and pack-years [85].

Polymorphisms of the GST genes are associated with the risk of lung cancer and are more frequent in small cell lung carcinoma and in the squamous cell carcinoma compared with the lung adenocarcinoma [85]. In addition, smokers with the GSTP1 Ile allele have an increased risk for the development of COPD [95]. Furthermore, the combination of GSTM1, GSTT1 null, and GSTP1 Val/Val is associated with the maximal increased risk (12-fold) of COPD [95].

A number of single nucleotide polymorphisms (SNPs) in COPD candidate genes TGF- $\beta_{1}$, EPHX1, SERPINE2, GSTP1 and ADRB2 have been associated with airway wall thickness and emphysema severity using computed tomography [96]. Finally, variants in the hedgehog interacting protein have been shown to have a protective effect in both COPD and lung cancer [97] (table 1).

The transcription factor nuclear factor E2-related factor 2 (Nrf2) increases the expression of several protective phase 2 detoxifying enzymes [such as GSTs and $\mathrm{NAD}(\mathrm{P}) \mathrm{H}$ :quinone oxidoreductase (NQO1)] and antioxidant enzymes such as peroxiredoxins [98]. Kelch-like ECH-associated protein 1 (Keap1) negatively regulates Nrf2 activity by targeting it to proteasomal degradation [99] and under normal conditions, low cellular concentrations of Nrf2 maintained by proteasomal degradation through a Keap1-dependent mechanism promote efficient ubiquitination and rapid turnover [98].

Common somatic mutations in the coding region of the Nrf2 gene resulting in increased cellular accumulation of Nrf2 are associated with poor prognosis in squamous cell lung carcinoma [98]. Mutations resulting in the loss of Keap1 function are more common in lung adenocarcinomas [99-101]. Interestingly, exposure of mice to cigarette smoke enhances oxidative damage and inflammation in the lungs via disruption of the Nrf2 gene [102] and a significant decrease in the Nrf2 protein level has been described in the COPD lungs [103-105]. This suggests that different changes in the Nrf2 pathway are involved in the development of COPD and lung cancer.

\section{Nicotine Addiction and Genetic Links between COPD and Lung Cancer}

SNPs located in a region of the long arm of the chromosome 15 (15q25.1) which contains the nicotinic acetylcholine receptor alpha (nAChR) subunits 3 (CHRNA3) and 5 (CHRNA5), and the $\beta 4 \mathrm{nAChR}$ subunit (CHRNB4) are significantly associated with lung cancer risk [106109 ] and account for $14 \%$ of the attributable risk of lung cancer cases [109]. Furthermore, the risk of lung cancer was more than 5-fold higher among subjects who had both a family history of lung cancer and two copies of the high-risk alleles located in this locus [110]. These SNPs in the 15q24-25.1 locus are extremely rare in Asians, and the three risk SNPs reported in Caucasians are not associated with lung cancer risk in Chinese [111]. However, other SNPs in this region are associated with significantly increased lung cancer risk and smoking behaviour in Asians possibly by affecting Oct-1 DNA binding, resulting in increased CHRNA3 expression [111]. Acetylcholine can promote the proliferation of neoplastic cells in 
vitro through $\mathrm{nAChRs}[112,113]$ and the proliferation of lung fibroblasts and myofibroblasts acting on muscarinic acetylcholine receptors [114]. Furthermore, nicotine stimulates mitogen-activated protein kinase (MAPK) (p44/42) and Akt-dependent proliferation and nuclear factor $\kappa \mathrm{B}(\mathrm{NF}-\kappa \mathrm{B})$-dependent survival of squamous cell lung cancer cell lines conferring a survival advantage to these cells [115]. This raises the possibility that chronic nicotine inhalation and/or endogenous acetylcholine released locally in the lung might both play a role in COPD and squamous cell lung carcinoma development in longterm smokers (table 1).

However, since these SNPs also tend to be associated with nicotine dependence, it is unlikely that the risk of lung cancer is independent of any effect they may have on smoking behaviour [116] although this may not be true in all circumstances. The rs16969968 15q SNP has a strong association with the risk of lung cancer that is independent of the association with smoking quantity [117].

\section{DNA Damage/Repair Mechanisms in Squamous Cell Lung Carcinoma and COPD Susceptibility}

The increased oxidative stress found in COPD either due to exogenous smoking or produced endogenously possibly in part due to the loss of Nrf2 activity can cause deoxyribonucleic acid (DNA) damage and carcinogenesis [118]. Damage to DNA induces several cellular responses that enable the cell to either eliminate or reverse the damage or to activate programmed cell death, presumably to eliminate cells with potentially catastrophic mutations [119]. These somatic mutations are usually associated with oncogenes but may also affect inflammatory signalling pathways such as the phosphoinositol 3-kinase (PI3K) pathway, impair host responses to viral and bacterial pathogens or alter drug responsiveness [118, 119 .

DNA repair mechanisms include direct repair, base excision repair, nucleotide excision repair, double-strand break repair, and cross-link repair [119]. Efficient repair of DNA double-strand breaks is essential for the maintenance of chromosomal integrity $[120,121]$. Doublestrand breaks are repaired either by homologous recombination or by non-homologous end joining (NHEJ) with the later being the primary pathway involved $[120,121]$. Six distinct proteins function in the NHEJ pathway (Ku70, Ku86, XRCC4, DNA ligase IV, Artemis, DNAPKcs) $[120,121]$. The heterotrimeric DNA-dependent protein kinase (DNA-PK) complex is a serine-threonine
Table 1. Genes potentially involved in lung carcinogenesis and COPD pathogenesis

CHRNA3

CHRNA5

CHRNB4

p53

p21WAP/CIP1

RB1

Hedgehog interacting protein

It is still not known whether there is an increased risk for the squamous cell carcinoma histological subtype.

kinase activated by the presence of double-strand breaks in DNA and composed of a catalytic subunit (DNA-PKcs) and the DNA-binding heterodimer of the regulatory subunits $\mathrm{Ku}$ proteins (Ku70 and Ku86). Autophosphorylation of DNA-PKcs [phospho-DNA-PKcs (pS2612)] correlates with loss of protein kinase activity and dissociation of the DNA-PKcs-Ku complex. DNA-PK is localized in the nucleus and it is critical during NHEJ because it initially recognizes and binds to the damaged DNA and then targets the other repair activities to the site of DNA damage [120-122]. In addition to the regulatory function of the $\mathrm{Ku}$ proteins in DNA-PK, heterodimers of both $\mathrm{Ku} 70$ and Ku 86 also have independent DNA repair functions [120-122]. In addition, oxidative stress can induce nuclear loss of $\mathrm{Ku}$ proteins in pancreatic cells in vitro [112].

A lack of DNA repair may be another common mechanism linking both COPD and squamous cell lung carcinoma [123]. For example, one possibility is that heritable genetic polymorphisms influence the efficiency of both DNA repair damage in the bronchial epithelium and connective tissue damage repair. It is also likely that genetic factors modulating the quality of DNA repair explain the absence of both COPD and squamous cell lung cancer in most smokers [124]. Several polymorphisms in DNA repair genes have already been reported to be associated with risk of squamous cell lung carcinoma [125]. Interestingly, women have a $10-15 \%$ lower capacity for repairing tobacco carcinogen-induced DNA damage than men [126]. DNA repair mechanisms also play an important role in the epigenetic regulation of cell function by mediating DNA demethylation [127] and may, in turn, be regulated by the epigenetic changes seen in lung cancer.

Recent evidence has determined a critical role for acetylation of histone $\mathrm{H} 3$ on lysine $56 \mathrm{AcH} 3 \mathrm{~K} 56$ in DNA 
damage and repair [128, 129]. Furthermore, deacetylation of AcH3K56 is controlled by histone deacetylases (HDACs) 1 and 2 and loss of HDAC1 and/or 2 can increase susceptibility to UV-A irradiation [128]. Sirtuins also play an important role in deacetylating H3K56 in mammalian cells $[129,130]$. This suggests that in diseases, such as COPD, where there is a decrease in HDAC2 [131] and SIRT1 $[132,133]$ expression, there may be less protection against DNA breakage and repair induced by environmental factors increasing the potential for somatic mutations and the risk of lung cancer. Clearly due to the complexity and the interrelationships of the many different pathways involved in the process of DNA repair in the lung this area deserves to be fully explored in larger studies.

\section{Cell Cycle Regulation and Apoptosis in Lung Carcinoma and COPD Susceptibility}

Alterations in cell cycle regulation and apoptosis leading to malignant transformation could be caused by common genetic variants in tumour suppressor genes, such as the protein p53 [134]. DNA damage triggers a 'danger response' coordinated by the ataxia-telangiectasia-mutated gene and p53 proteins. This response to oxidative stress, for stress for example, aims to lessen the cellular damage as cells go into a waiting period for DNA repair, but can become permanent when cells have dangerously shortened telomeres (the DNA-protective TTAGG repeats at the end of chromosomes). This ultimately leads to cell senescence (replicative senescence), which is apoptosis resistant and metabolically active but unable to proliferate beyond the G1 stage of the cell cycle [134].

Cigarette smoking significantly increases lung cancer risk in carriers of a germline p53 mutation [135] and some p53 SNPs have been associated with an increased risk of developing COPD [136, 137]. The tumour suppressor gene $\mathrm{p} 21^{\mathrm{WAP} / \mathrm{CIP} 1}$ is transcriptionally activated by $\mathrm{p} 53$ to induce cell cycle arrest and DNA repair. $\mathrm{p} 21^{\mathrm{WAP} / \mathrm{CIP} 1}$ protein expression is increased in alveolar macrophages and bronchial epithelial cells of patients with COPD and is highly responsive to oxidative stress resulting in cytoplasmic translocation and inhibition of apoptosis of these cells [138]. A p21 ${ }^{\mathrm{WAP} / \mathrm{CIP} 1} \mathrm{SNP}$ is linked to a high risk for COPD in Taiwanese smokers [137]. These data suggest that an increased expression of $\mathrm{p} 21^{\mathrm{WAP} / \mathrm{CIP} 1}$ in the lower airways caused by chronic exposure to tobacco smoking may represent another potential molecular link between COPD and squamous cell lung carcinoma (table 1).
The peripheral lung of the COPD patients contains higher percentages of pro-inflammatory senescent type 2 alveolar cells that co-express the cell cycle inhibitor p16 ${ }^{\text {INK4a }}$ as well as phosphorylated NF- $\mathrm{BB}[139,140]$. p16 ${ }^{\mathrm{INK} 4 \mathrm{a}}$ promoter methylation in the bronchial epithelium is very frequent among NSCLC patients and cancerfree controls and persists after smoking cessation [141143].

\section{Epigenetic Mechanisms Linking Lung Cancer and COPD Susceptibility}

Epigenetic modifications are potentially heritable changes that alter gene expression and cell function without DNA sequence alterations [144]. These changes include DNA methylation and posttranslational modifications of histones (histone acetylation, methylation, ubiquitination, sumoylation and phosphorylation), which together control chromatin structure and remodelling and that ultimately control the transcriptional outcome of the cell [145]. The main epigenetic alterations associated with lung cancer are DNA promoter hypermethylation, DNA global hypomethylation, posttranslational modification of histones and miRNA silencing by DNA hypermethylation [146].

DNA methylation has critical roles in the control of gene activity and the architecture of the nucleus of the cell because it is usually associated with gene silencing [147]. DNA methylation occurs on cytosines within dinucleotide CpGs. CpG sites are not randomly distributed in the genome but are generally clustered at the $5^{\prime}$ end of the regulatory region of many genes in areas known as CpG islands [147] although they may also occur proximal to transcriptional start sites at CpG island shores [148]. The maintenance of these methyl CpG marks is due to the action of a number of DNA methyltransferases (DNMTs) which add the universal methyl donor S-adenosylL-methionine to cytosine. DNMT1 is considered to be a maintenance DNMT whereas DNMT3s are involved with de novo methylation [149].

Normal tissues from individuals show similar overall DNA methylation patterns in contrast to the several hundred hypermethylated $\mathrm{CpG}$ islands found in each lung squamous cell carcinoma. Of these, eleven $\mathrm{CpG}$ islands were methylated in $80-100 \%$ of the lung squamous cell carcinomas. In addition, extensive DNA hypomethylation in the lung squamous cell carcinomas occurs specifically at repetitive sequences, including short and long interspersed nuclear elements and long 
terminal repeat elements, segmental duplications, and subtelomeric regions [150]. Aberrant methylation of the p16 ${ }^{I N K 4 a}$ tumour suppressor gene and/or $\mathrm{O}^{6}$-methylguanine-DNA methyltransferase (MGMT) promoters can be detected in DNA from sputum in $100 \%$ of patients with squamous cell lung carcinoma up to 3 years before clinical diagno-sis [151], and has thus been proposed as a biomarker for early detection of squamous cell lung cancer [152]. The DNA hypermethylation status of the p16 ${ }^{I N K 4 a}, \mathrm{CDH} 13, \mathrm{RASSF} 1 \mathrm{~A}$, and APC genes is also associated with an increased risk for recurrence following surgical resection of early NSCLC and with detection of methylated DNA in histologically negative lymph nodes [153].

MGMT hypermethylation is more common in squamous cell carcinomas in males and smokers than in adenocarcinomas in females and non-smokers. $17 \beta$-Oestradiol decreases DNMT1 and HDAC1 protein expression and their binding activity on the MGMT promoter in lung cancer cell lines and this may partially contribute to the MGMT hypermethylation gender difference seen in lung cancer [154].

Chronic exposure of human airway epithelial cells causes a specific gene expression signature linked to changes in cell function including an increase in soft agar clonogenicity and activation of Wnt signalling [155]. In addition, the authors reported a concentration- and timedependent change in global epigenetic marks. Thus, there is a diminution of $\mathrm{H} 4 \mathrm{~K} 16 \mathrm{Ac}$ and $\mathrm{H} 4 \mathrm{~K} 20 \mathrm{Me} 3$ marks and increasing levels of H3K27Me3 [155]. Furthermore, there is a time-dependent global hypomethylation including that of D4Z4, NBL2, and LINE-1 repetitive DNA sequences along with gene-specific hypermethylation of TSGs such as RASSF1A and RAR- $\beta$ [155]. Collectively, these data indicate that cigarette smoke induces 'cancerassociated' epigenomic alterations in cultured respiratory epithelia. Little is currently known about these effects in COPD although this is an area of active research.

\section{Micro-RNA}

miRNAs are small non-coding RNAs that regulate protein expression either through actions on mRNAs synthesis or translation and function as key controllers in a myriad of cellular processes, including proliferation, differentiation and apoptosis. miRNAs can function as tumour suppressors and oncogenes [156] and mutation, misexpression, and altered miRNA processing are all implicated in carcinogenesis and/or tu- mour progression. Aberrant expression or function of miRNAs may result from SNPs affecting their sequence, expression, or binding to target sites [156] or through epigenetic alterations, resulting in aberrant patterns of expression [145]. Increased expression of mir-196a2 due to a specific SNP is associated with a significantly decreased survival in patients with early NSCLC [156] and an increased susceptibility to lung cancer in Chinese populations [157].

Twenty-eight miRNAs are differentially expressed in bronchial airway epithelium from current and neversmokers with the majority being downregulated in smokers. Furthermore, regulation of one of these miRs (miR218 ) by cigarette smoke exposure was able to regulate the airway epithelial gene expression response [158]. In addition, 34/627 miRNAs were differentially expressed in induced sputum supernatant between never-smokers and current smokers without airflow limitation. Reduced expression of let-7c and miR-125b was confirmed in COPD by validation in a second cohort. Importantly, let-7c target genes such as TNF receptor type II were inversely correlated with let-7c expression in the sputum of patients with severe COPD [159].

Finally, fibroblasts from COPD patients produce more cyclooxygenase (COX)-2 and its product prostaglandin (PG) $E_{2}$ than those from healthy smokers following stimulation [160]. COX-2 expression is regulated by miR-146a whose expression was differentially enhanced by fibroblast stimulation, implicating a pathogenic role in the abnormal inflammatory response in COPD [160].

\section{Inflammation in COPD May Drive the Development of Human Squamous Cell Lung Carcinoma}

As described above, COPD is a chronic inflammatory disease of the lower airways characterized by the accumulation of macrophages, CD4+ and CD8+ T cells, dendritic cells, B cells and neutrophils, particularly in smaller airways and lung parenchyma, and the severity of COPD is associated with the degree of infiltration by these inflammatory cells [1]. A causal relation between inflammation and cancer was initially proposed by Galen and later by Virchow, who noticed the infiltration of leucocytes in malignant tissues and suggested that cancers arise at regions of chronic inflammation. The longer the inflammation persists, the higher the risk of asso-ciated carcinogenesis [reviewed in 161]. However, the mechanism by which chronic lower airway inflammation is linked to lung carcinogenesis is still not completely understood [162]. 
Inflammatory mediators in the BASC microenvironment may promote neoplasia by inducing proneoplastic mutations, proliferation, resistance to apoptosis, angiogenesis, invasion, metastasis, and secretion of immunosuppressive factors. In fact, inflammatory cells such as macrophages and $\mathrm{T}$ lymphocytes can communicate with the neoplastic cells through a reciprocal and self-perpetuating interaction, resulting in increased growth and resistance to immune destruction [163]. All these changes confer a survival advantage to the neoplastic cell.

We review below some of the inflammatory mediators and intracellular signalling pathways potentially relevant in the pathogenic link between COPD and lung cancer.

\section{Inflammatory Mediators in COPD and Lung Cancer Chemokines, Their Receptors and Heterogeneous Nuclear Ribonucleoproteins in COPD and Lung Cancer}

Activation of the CXCR4/CXCL12 (SDF-1) axis may have a role in the pathogenesis of lung cancer. In fact, neutralization of CXCL12 by anti-CXCL12 or antiCXCR4 monoclonal antibody in preclinical in vivo studies results in a significant decrease in NSCLC metastases [164]. Activation of the CXCR4/CXCL12 (SDF-1) axis also induces nuclear export of the heterogeneous nuclear ribonucleoprotein (hnRNP) A2/B1 [165]. hnRNPs comprise a family of multifunctional proteins that regulate mRNA processing, transport and subcellular localization, telomere stability, cell senescence and cell cycle regulation [165] and hnRNP A2/B1 may also have a role in cell migration [166].

Overexpression of hnRNP A2/B1 in plasma and primary human bronchial epithelium has a high sensitivity for the presence of NSCLC, particularly squamous cell carcinoma, and is also present in high-risk smokers years before they develop lung cancer $[167,168]$. The role of the CXCR4/CXCL12 axis and of hnRNP A2/B1 in the pathogenesis of COPD and in the associated lung carcinogenesis should be explored.

\section{Prostaglandins in COPD and Lung Cancer}

The enzyme COX-2 and its product $\mathrm{PGE}_{2}$ may enhance the inflammatory response as well as carcinogenesis through effects on cell proliferation, apoptosis and angiogenesis and may be involved in the pathogenesis of both COPD and lung cancer. The sputum levels of $\mathrm{PGE}_{2}$ and COX-2 activity are increased in smokers with COPD compared to non-smoking control subjects and the sputum levels of $\mathrm{PGE}_{2}$ are inversely correlated with percent predicted $\mathrm{FEV}_{1}$ in COPD patients [169]. COX-2 expression is also increased in the peripheral lung of COPD patients compared to control subjects [170].

Many epidemiological studies suggest that there is a decreased incidence of lung cancer, particularly of adenocarcinoma, in subjects who regularly use aspirin or other COX inhibitors $[171,172]$ and a daily intake of aspirin or ibuprofen, for 5 or more years, reduces the risk of lung cancer by $36 \%$ [173]. Carriers of the $\mathrm{C}$ allele of a common polymorphism in the $3^{\prime}$-UTR of COX-2, associated with a reduced production of COX-2, have a significantly increased risk of lung cancer [174].

\section{Intracellular Signalling Pathways in COPD and Lung Cancer}

The transcription factor, NF- $\kappa \mathrm{B}$, is activated by inflammatory mediators and by oxidative stress and may provide a molecular link between inflammation and lung cancer [175] as it is activated in the bronchial epithelium and in inflammatory cells both in the lower airways of COPD patients and in the premalignant lesions of the bronchial epithelium and neoplastic cells of squamous cell lung carcinoma [176-179].

NF- $\kappa \mathrm{B}$ activation and subsequent transactivation of inflammation-related genes may play a central role in both COPD and squamous cell lung carcinoma [175]. Indeed, in addition to its tumour-promoting role, which depends on stimulation of cell proliferation and inhibition of cell death, NF- $\kappa \mathrm{B}$ may also participate in tumour initiation [180]. For instance, NF- $\kappa B$-activated macrophages in the bronchial tissues of COPD patients can release oxidants in the proximity of the basal bronchial epithelial cells to cause their DNA damage. In addition, NF- $\kappa B$-driven expression of pro-inflammatory cytokines may also promote tumour angiogenesis, which accelerates cell growth and metastases. Recent evidence suggests that prolonged exposure to cigarette smoke induces lung cancer in animals following induction of an NF- $\kappa \mathrm{B}$-dependent inflammatory response in the lower airways [181]. More subtle modulation of NF- $\mathrm{KB}$ activity by PKC zeta (PKC $\zeta)$ [182], for example, may reduce the risk of infection associated with chronic dosing with NF- $\kappa$ B inhibitors [183].

PI3K and glycogen synthase kinase-3 signalling upregulated in COPD [184] is important in airway inflammation and corticosteroid responsiveness [185]. PI3K is 
also implicated in the control of Dnmt3a expression and the specific methylation and altered expression of selective imprinted genes in stem cells [186]. In addition, smoking induces a PI3K-characteristic genomic signature in human airway epithelial cells in vivo prior to tumorigenesis. Furthermore, successful treatment of dysplasia by the PI3K inhibitor myo-inositol attenuated the PI3K signature [187]. These data indicate that abnormal activation of the PI3K pathway in the bronchial airway epithelium of smokers is an early, measurable, and reversible event in the development of lung cancer. Targeting the PI3K pathway may be a suitable therapeutic approach for both COPD and lung cancer.

Other kinase signalling pathways are also likely to be important. As well as playing a critical role in the inflammatory response in COPD and being implicated in steroid responsiveness [27], the p38 MAPK pathway is upregulated and may play critical roles in lung cancer [188]. This is particularly the case in non-smokers with lung cancer where lifelong non-smoking is associated with high levels of activated p38 MAPK in patients with lung adenocarcinoma [189]. In addition, p38 MAPK has been shown to be important for metastasis through the formation of tumour-platelet aggregates and their interaction with the endothelium [190]. Furthermore, the cytoxic effects of cisplatin, for example, are mediated through targeting the p38 MAPK pathway [191]. However, mice lacking $\mathrm{p} 38 \alpha$ are more susceptible to cancer development in carcinogen or oncogene-induced cancer models [192]. p38 $\alpha$ can also suppress cell proliferation by antagonizing the JNK/c-Jun pathway, which is an important regulator of proliferation and apoptosis [192], therefore suggesting that a combined p38MAPK/JNK approach may be better for targeting lung cancer inflammation.

There is evidence for abnormal activation of the Janus kinase (JAKs)/signal transducers and activators of transcription (STAT) signalling pathways in lung cancer [193] which may be related to the hypermethylation of the suppressor of cytokine signalling (SOCS)3 promoter [194]. In lung cancer, STAT3 can be activated by multiple pathways, including EGFR, $\alpha 7$ nicotinic receptor, numerous cytokines and erythropoietin receptor pathways [193]. Suppression of JAK/STAT activity induces cell apoptosis and suppresses growth [194]. IL-6 production is implicated in the pathogenesis, progression and drug resistance in cancer and, along with the NF- $\kappa \mathrm{B}$ and PI3K/Akt pathways, the JAK/STAT pathway is important in controlling the autocrine production of IL- 6 from lung cancer cells [195]. Therefore, regulation of this pathway may be useful for the treatment of lung cancer.
Peroxisome proliferator-activated receptors (PPARs) are ligand-activated transcription factors that belong to the nuclear hormone receptor superfamily. PPAR $\gamma$ regulates several metabolic pathways by binding to sequencespecific PPAR response elements in the promoter region of the target genes [196]. PPAR $\gamma$ regulates cell growth by inducing differentiation and apoptosis. These effects are mediated through inhibition of transcription factors, including NF-кB. PPAR $\gamma$ ligands inhibit the release of proinflammatory cytokines from airway epithelial cells and play an important role in regulating their differentiation. In an animal model of COPD-like airway inflammation the PPAR $y$ agonist, rosiglitazone, inhibits lipopolysaccharide-induced neutrophilia and reduces chemoattractants and survival factors [196]. Decreased expression of PPAR $\gamma$ has been observed in lung cancer [197].

HDAC2 which is important in many cell functions including NF- $\kappa \mathrm{B}$ activation and glucocorticoid function is reduced in COPD [131]. Activation of HDAC2 activity by low-dose theophylline restores steroid responsiveness in COPD patients on inhaled corticosteroids, resulting in an improvement in inflammatory indices and lung function [198]. Since HDAC2 is also involved in the DNA repair process the combination of low-dose theophylline and corticosteroid may also prevent the progression to lung cancer. Similarly, sirtuin 1 (SIRT1), a member of the silent information regulator 2 in mammals, has also recently been found to be reduced in the peripheral lung of COPD patients $[132,133]$. SIRT1 is known to be able to deacetylate a number of important signalling proteins such as p53 and NF- $\kappa$ B and in the case of NF- $\kappa$ B, deacetylation attenuates NF- $\kappa B$ transcriptional activation [199].

\section{Oxidants in COPD and Lung Cancer}

Oxidative stress can amplify the inflammatory response and the loss of Nrf2 activity in COPD lungs may contribute to the increased susceptibility of COPD patients to lung cancer by regulating the expression of many anti-oxidant and detoxifying enzymes and thereby enhancing lung inflammation [104, 200]. In addition, oxidative stress also increases cytoplasmic expression of $\mathrm{p} 21^{\mathrm{WAP} / \mathrm{CIP} 1}$ and promotes the transition from the G1 to the G2/M phase of the cell cycle, resulting in an imbalance of apoptosis/proliferation towards hyperproliferation in lung epithelial cells [138]. This may enhance the epithelial transition from normal to hyperplastic and finally to carcinomatous status in smokers and patients with COPD. Oxidative stress may also induce somatic 
Table 2. New potential compounds for the treatment of both lung cancer and COPD

Wide-spectrum anti-inflammatory compounds

Inhaled glucocorticoids

COX-2-selective inhibitors

Novel inhibitors and combinations, e.g. low-dose

theophylline and glucocorticoids

Selective antagonists of inflammatory mediators

Muscarinic M3 receptor antagonists

CXCR4/CXCL12 axis blockers

Signalling pathway modulators

NF- $\kappa$ B blockers

PI3K inhibitors

Selective PKC subtype inhibitors

p38 MAPK inhibitors

Janus kinase inhibitors

PPAR $\gamma$ agonists

mutations in DNA [118] and may also affect DNA methylation by the formation of 8-hydroxy-2'-deoxyguanosine residues since the presence of these residues affects DNMT1 DNA binding to the TGF- $\beta_{1}$ promoter [201].

\section{New Potential Pharmacological Therapies for Both Lung Cancer and COPD}

Smoking cessation should be encouraged in all smokers but even if all smokers stopped there would still be a large number of patients suffering from COPD and lung cancer over the next decades. At present there are many compounds in development or under study (table 2) that either prevent lung cancer in animal models or demonstrate efficacy in human epidemiological and small clinical studies. However, few of these have been proven effective in large controlled clinical trials. Recently, the oral EGFR tyrosine kinase inhibitor erlotinib was shown to be well tolerated and significantly prolongs progression-free survival in a phase 3 placebo-controlled study of 889 subjects with unresectable NSCLC (SATURN; BO18192) following first-line platinum-doublet chemotherapy [202]. EGFR is involved in mucus hypersecretion so EGFR inhibitors might be expected to reduce chronic bronchitis. However, a recent study with an inhaled EGFR inhibitor (BIBW 2948) showed no effect on mucus secretion in COPD patients [203].

In animal models of lung cancer, inhaled glucocorticoids have a protective effect and reverse DNA hypomethylation and modulate mRNA expression of oncogenes
[204] and epidemiological studies suggest that regular use of inhaled glucocorticoids, with and without long-acting inhaled $\beta_{2}$-agonists, may reduce the risk of lung cancer among former smokers with diagnosed COPD [205]. However, a 6-month treatment with high doses of inhaled glucocorticoids does not cause any regression of bronchial dysplasia or secondary markers of carcinogenesis in smokers [206-208] and a long-term clinical trial in moderate to severe COPD patients treated for 3 years with inhaled glucocorticoids has not demonstrated a decreased risk of lung cancer [209]. There is an ongoing chemoprevention trial measuring the effect of inhaled fluticasone propionate in high-risk smokers (however, patients with $\mathrm{FEV}_{1}$ less than 1 litre have been excluded from this study) [206]. The addition of low-dose theophylline to combination therapy may have additional benefits [198].

Normal bronchial epithelium and squamous cell lung carcinomas synthesize and release ACh which can stimulate tumour growth by binding to nicotinic and muscarinic receptors expressed on lung cancers [210, 211]. Thus antagonists to nicotinic and muscarinic receptors can inhibit lung cancer growth. The muscarinic receptor (mAChR) subtype utilized for cell proliferation is the M3 subtype and consistent with this M3 mAChR antagonists inhibit growth of squamous cell carcinomas [210, 211]. However, a long-term clinical trial in moderate to severe COPD patients treated for 3 years with inhaled tiotropium (a strong M3 blocker) has no demonstrable effect on the risk of lung cancer [212]. Due to the safety of these drugs and their wide use in clinical practice for the treatment of COPD, more long-term controlled clinical trials should be designed to specifically address this issue.

In a series of case-control studies, daily use of a selective COX-2 inhibitor, either celecoxib or rofecoxib, significantly reduced the risk for lung cancer; however, the use of these drugs increased the relative risk of cardiovascular disease [173].

Many different signal transduction pathways, originating from a wide variety of cellular stresses and stimuli, converge on a single target, the NF- $\kappa \mathrm{B} / \mathrm{I} \mathrm{B}$ complex and its activating kinase (inhibitor of $\kappa \mathrm{B}$ kinase, IKK). IKK2 inhibitors are in development as novel therapies for the treatment of COPD [183] and lung cancer [213]. Interestingly, in vitro, inhibition of NF- $\mathrm{B}$ using bortezomib or the compound BAY 11-7085 sensitizes squamous cell lung carcinoma cell lines to death induced by histone deacetylase inhibitors [214, 215]. NF-кB inhibition suppresses airway inflammation in animals [183] and urethane-induced lung cancer [216]. Interestingly, p53 may also suppress NF$\kappa \mathrm{B}$ activity in animal models of airway inflammation 
[217]. The potential benefit of inhibiting several other signalling pathways such as PI3K, p38 MAPK, PKC $\zeta$ and $\mathrm{PKC} \mathrm{\iota}$ has been discussed above and results from clinical trials in COPD as well as lung cancer are awaited.

As described above, there is a clear role for oxidative stress in driving the inflammatory response in COPD and inducing lung cancer. Anti-oxidant strategies should, therefore, be of use in both diseases [218]. A long-term clinical trial in moderate to severe COPD patients treated for 3 years with the anti-oxidant $\mathrm{N}$-acetylcysteine $(600 \mathrm{mg}$ daily) did not demonstrate a decreased risk of lung cancer [219]. Similarly in the large EUROSCAN trial, neither vitamin A nor $\mathrm{N}$-acetylcysteine (600 mg daily) could prevent tumour recurrence or the occurrence of second primary tumours in patients with lung cancer during the 2 -year follow-up period [220]. However, the doses used in these studies may not have produced a local anti-oxidant effect. The development of bioavailable mitochondrially directed drugs may enhance the intracellular anti-oxidant capacity and thus effectiveness of this approach $[221,222]$.

\section{Conclusions}

Many new compounds that target the molecular pathology of advanced squamous cell lung carcinoma are now undergoing clinical trials. However, it is likely that a greater understanding of the molecular and cellular pathobiology that distinguishes smokers with premalignant bronchial lesions and squamous cell lung cancer from smokers with and without COPD is needed to unravel the complex molecular interactions between COPD and lung cancer. These studies should also look at younger healthy smokers in combination with risk models of lung cancer and COPD. Overall these studies may allow the discovery of new molecular targets of the early carcinogenesis process that in the foreseeable future may render the early diagnosis and treatment, and maybe even the prevention, of invasive squamous cell lung carcinoma a reality. By understanding the common signalling pathways involved in COPD and lung cancer the hope is that treatments will be developed that not only treat the underlying disease process in COPD, but also reduce the currently high risk of developing lung cancer in these patients.

\section{Acknowledgements}

We thank The Wellcome Trust, The Biotechnology and Biological Sciences Research Council (BBSRC), The Medical Research Council (UK), GlaxoSmithKline and Pfizer for supporting current research in our laboratories.

\section{References}

1 National Institutes of Health, National Heart, Lung and Blood Institute. Global Initiative for Chronic Obstructive Lung Disease (GOLD): Global strategy for the diagnosis, management and prevention of chronic obstructive pulmonary disease. NHLBI/WHO workshop report. NIH Publication No 2701A, March 2001. www goldcopd com (accessibility verified May 15, 2010).

2 Salvi SS, Barnes PJ: Chronic obstructive pulmonary disease in non-smokers. Lancet 2009;374:733-743.

3 Lopez AD, Mathers CD, Ezzati M, Jamison DT, Murray CJ: Global and regional burden of disease and risk factors, 2001: systematic analysis of population health data. Lancet 2006;367:1747-1757.

4 Sin DD, Man SF: Systemic inflammation and mortality in chronic obstructive pulmonary disease. Can J Physiol Pharmacol 2007;85: 141-147.
${ }_{5}$ Ben-Zaken CS, Pare PD, Man SF, Sin DD: The growing burden of chronic obstructive pulmonary disease and lung cancer in women: examining sex differences in cigarette smoke metabolism. Am J Respir Crit Care Med 2007;176:113-120.

6 Mannino DM: Epidemiology and global impact of chronic obstructive pulmonary disease. Semin Respir Crit Care Med 2005;26: 204-210.

7 Punturieri A, Szabo E, Croxton TL, Shapiro SD, Dubinett SM: Lung cancer and chronic obstructive pulmonary disease: needs and opportunities for integrated research. J Natl Cancer Inst 2009;101:554-559.

$\checkmark 8$ Purdue MP, Gold L, Jarvholm B, Alavanja MC, Ward MH, Vermeulen R: Impaired lung function and lung cancer incidence in a cohort of Swedish construction workers. Tho$\operatorname{rax} 2007 ; 62: 51-56$.

-9 Tockman MS, Anthonisen NR, Wright EC, Donithan MG: Airways obstruction and the risk for lung cancer. Ann Intern Med 1987; 106:512-518.
10 Young RP, Hopkins RJ, Christmas T, Black PN, Metcalf P, Gamble GD: COPD prevalence is increased in lung cancer, independent of age, sex and smoking history. Eur Respir J 2009;34:380-386.

-11 Wasswa-Kintu S, Gan WQ, Man SF, Pare PD, Sin DD: Relationship between reduced forced expiratory volume in one second and the risk of lung cancer: a systematic review and meta-analysis. Thorax 2005;60:570575 .

12 Seibold MA, Schwartz DA: The lung: the natural boundary between nature and nurture. Annu Rev Physiol 2010, E-pub ahead of print.

13 Schwartz DA: Epigenetics and environmental lung disease. Proc Am Thorac Soc 2010;7: 123-125.

14 Abidoye O, Ferguson MK, Salgia R: Lung carcinoma in African Americans. Nat Clin Pract Oncol 2007;4:118-129.

15 Jemal A, Siegel R, Ward E, Hao Y, Xu J, Thun MJ: Cancer statistics, 2009. CA Cancer J Clin 2009;59:225-249. 
$\checkmark 16$ Youlden DR, Cramb SM, Baade PD: The international epidemiology of lung cancer: geographical distribution and secular trends. J Thorac Oncol 2008;3:819-831.

$\checkmark 17$ Egleston BL, Meireles SI, Flieder DB, Clapper ML: Population-based trends in lung cancer incidence in women. Semin Oncol 2009;36:506-515.

18 Scagliotti GV, Longo M, Novello S: Nonsmall cell lung cancer in never smokers. Curr Opin Oncol 2009;21:99-104.

-19 Anthonisen NR, Skeans MA, Wise RA, Manfreda J, Kanner RE, Connett JE: The effects of a smoking cessation intervention on 14.5-year mortality: a randomized clinical trial. Ann Intern Med 2005; 142:233-239.

20 Yao H, Rahman I: Current concepts on the role of inflammation in COPD and lung cancer. Curr Opin Pharmacol 2009;9:375383.

-21 Molina JR, Yang P, Cassivi SD, Schild SE, Adjei AA: Non-small cell lung cancer: epidemiology, risk factors, treatment, and survivorship. Mayo Clin Proc 2008;83:584-594.

-22 Papi A, Casoni G, Caramori G, Guzzinati I, Boschetto P, Ravenna F, Calia N, Petruzzelli S, Corbetta L, Cavallesco G, Forini E, Saetta M, Ciaccia A, Fabbri LM: COPD increases the risk of squamous histological subtype in smokers who develop non-small cell lung carcinoma. Thorax 2004;59:679-681.

-23 Janssen-Heijnen ML, Coebergh JW: Trends in incidence and prognosis of the histological subtypes of lung cancer in North America, Australia, New Zealand and Europe. Lung Cancer 2001;31:123-137.

24 Carney DN: Lung cancer - time to move on from chemotherapy. N Engl J Med 2002;346: 126-128.

25 Parkin DM, Bray F, Ferlay J, Pisani P: Global cancer statistics, 2002. CA Cancer J Clin 2005;55:74-108.

-26 Hogg JC, Chu F, Utokaparch S, Woods R, Elliott WM, Buzatu L, Cherniack RM, Rogers RM, Sciurba FC, Coxson HO, Pare PD: The nature of small-airway obstruction in chronic obstructive pulmonary disease. N Engl J Med 2004;350:2645-2653.

27 Chung KF, Adcock IM: Multifaceted mechanisms in COPD: inflammation, immunity, and tissue repair and destruction. Eur Respir J 2008;31:1334-1356.

28 Hogg JC: Pathophysiology of airflow limitation in chronic obstructive pulmonary disease. Lancet 2004;364:709-721.

29 Barnes PJ: Alveolar macrophages in chronic obstructive pulmonary disease (COPD). Cell Mol Biol (Noisy-le-grand) 2004;50 Online Pub: OL627-OL637.

30 Barnes PJ: Medicine. Neutrophils find smoke attractive. Science 2010;330:40-41.
31 Lacoste JY, Bousquet J, Chanez P, Van Vyve T, Simony-Lafontaine J, Lequeu N, Vic P, Enander I, Godard P, Michel FB: Eosinophilic and neutrophilic inflammation in asthma, chronic bronchitis, and chronic obstructive pulmonary disease. J Allergy Clin Immunol 1993;92:537-548.

- 32 Linden M, Rasmussen JB, Piitulainen E, Tunek A, Larson $M$, Tegner $H$, Venge $P$, Laitinen LA, Brattsand R: Airway inflammation in smokers with nonobstructive and obstructive chronic bronchitis. Am Rev Respir Dis 1993;148:1226-1232.

33 Fujimoto K, Kubo K, Yamamoto H, Yamaguchi S, Matsuzawa Y: Eosinophilic inflammation in the airway is related to glucocorticoid reversibility in patients with pulmonary emphysema. Chest 1999;115:697-702.

34 Panzner P, Lafitte JJ, Tsicopoulos A, Hamid Q, Tulic MK: Marked up-regulation of T lymphocytes and expression of interleukin-9 in bronchial biopsies from patients with chronic bronchitis with obstruction. Chest 2003;124:1909-1915.

35 Lams BE, Sousa AR, Rees PJ, Lee TH: Immunopathology of the small-airway submucosa in smokers with and without chronic obstructive pulmonary disease. Am J Respir Crit Care Med 1998;158:1518-1523.

- 36 Chanez P, Vignola AM, O’Shaugnessy T, Enander I, Li D, Jeffery PK, Bousquet J: Corticosteroid reversibility in COPD is related to features of asthma. Am J Respir Crit Care Med 1997;155:1529-1534.

- 37 Pizzichini E, Pizzichini MM, Gibson P, Parameswaran K, Gleich GJ, Berman L, Dolovich J, Hargreave FE: Sputum eosinophilia predicts benefit from prednisone in smokers with chronic obstructive bronchitis. Am J Respir Crit Care Med 1998;158:15111517.

38 Fujimoto K, Kubo K, Yamamoto H, Yamaguchi S, Matsuzawa Y: Eosinophilic inflammation in the airway is related to glucocorticoid reversibility in patients with pulmonary emphysema. Chest 1999;115:697-702.

-39 O'Shaughnessy TC, Ansari TW, Barnes NC, Jeffery PK: Inflammation in bronchial biopsies of subjects with chronic bronchitis: inverse relationship of $\mathrm{CD} 8+\mathrm{T}$ lymphocytes with FEV1. Am J Respir Crit Care Med 1997; 155:852-857.

40 van der Strate BW, Postma DS, Brandsma CA, Melgert BN, Luinge MA, Geerlings M, Hylkema MN, van den BA, Timens W, Kerstjens HA: Cigarette smoke-induced emphysema: a role for the B cell? Am J Respir Crit Care Med 2006;173:751-758.

41 Lee SH, Goswami S, Grudo A, Song LZ, Bandi V, Goodnight-White S, Green L, HackenBitar J, Huh J, Bakaeen F, Coxson HO, Cogswell S, Storness-Bliss C, Corry DB, Kheradmand F: Antielastin autoimmunity in tobacco smoking-induced emphysema. Nat Med 2007;13:567-569.
42 Demedts IK, Bracke KR, Van Pottelberge G, Testelmans D, Verleden GM, Vermassen FE, Joos GF, Brusselle GG: Accumulation of dendritic cells and increased CCL20 levels in the airways of patients with chronic obstructive pulmonary disease. Am J Respir Crit Care Med 2007;175:998-1005.

43 Innes AL, Woodruff PG, Ferrando RE, Donnelly S, Dolganov GM, Lazarus SC, Fahy JV: Epithelial mucin stores are increased in the large airways of smokers with airflow obstruction. Chest 2006;130:1102-1108.

44 de Marco R, Accordini S, Cerveri I, Corsico A, Anto JM, Kunzli N, Janson C, Sunyer J, Jarvis D, Chinn S, Vermeire P, Svanes C, Ackermann-Liebrich U, Gislason T, Heinrich J, Leynaert B, Neukirch F, Schouten JP, Wjst M, Burney P: Incidence of chronic obstructive pulmonary disease in a cohort of young adults according to the presence of chronic cough and phlegm. Am J Respir Crit Care Med 2007;175:32-39.

45 Puchelle E, Zahm JM, Tournier JM, Coraux C: Airway epithelial repair, regeneration, and remodeling after injury in chronic obstructive pulmonary disease. Proc Am Thorac Soc 2006;3:726-733.

-46 Cosio M, Ghezzo H, Hogg JC, Corbin R, Loveland M, Dosman J, Macklem PT: The relations between structural changes in small airways and pulmonary-function tests. N Engl J Med 1978;298:1277-1281.

$>47$ Kelsen SG, Duan X, Ji R, Perez O, Liu C, Merali S: Cigarette smoke induces an unfolded protein response in the human lung: a proteomic approach. Am J Respir Cell Mol Biol 2008;38:541-550.

-48 O’Donnell RA, Richter A, Ward J, Angco G, Mehta A, Rousseau K, Swallow DM, Holgate ST, Djukanovic R, Davies DE, Wilson SJ: Expression of ErbB receptors and mucins in the airways of long-term current smokers. Tho$\operatorname{rax} 2004 ; 59: 1032-1040$.

49 Kurie JM, Shin HJ, Lee JS, Morice RC, Ro JY, Lippman SM, Hittelman WN, Yu R, Lee JJ, Hong WK: Increased epidermal growth factor receptor expression in metaplastic bronchial epithelium. Clin Cancer Res 1996;2: 1787-1793.

50 Lapperre TS, Sont JK, van Schadewijk A, Gosman MM, Postma DS, Bajema IM, Timens W, Mauad T, Hiemstra PS, GLUCOLD Study Group: Smoking cessation and bronchial epithelial remodelling in COPD: a cross-sectional study. Respir Res 2007;8:85.

-51 Franklin WA, Veve R, Hirsch FR, Helfrich BA, Bunn PA Jr: Epidermal growth factor receptor family in lung cancer and premalignancy. Semin Oncol 2002;29:3-14.

52 Wistuba II, Lam S, Behrens C, Virmani AK, Fong KM, LeRiche J, Samet JM, Srivastava S, Minna JD, Gazdar AF: Molecular damage in the bronchial epithelium of current and former smokers. J Natl Cancer Inst 1997;89: 1366-1373. 
53 Franklin WA, Gazdar AF, Haney J, Wistuba II, La Rosa FG, Kennedy T, Ritchey DM, Miller YE: Widely dispersed p53 mutation in respiratory epithelium. A novel mechanism for field carcinogenesis. J Clin Invest 1997; 100:2133-2137.

54 Burgel PR, Nadel JA: Roles of epidermal growth factor receptor activation in epithelial cell repair and mucin production in airway epithelium. Thorax 2004;59:992-996.

- 55 Auerbach O, Hammond EC, Garfinkel L: Changes in bronchial epithelium in relation to cigarette smoking, $1955-1960$ vs. $1970-$ 1977. N Engl J Med 1979;300:381-385.

- 56 Steiling K, Ryan J, Brody JS, Spira A: The field of tissue injury in the lung and airway. Cancer Prev Res (Phila) 2008;1:396-403.

57 Wistuba II: Genetics of preneoplasia: lessons from lung cancer. Curr Mol Med 2007;7:314.

-58 Segal RA, Martonen TB, Kim CS, Shearer M: Computer simulations of particle deposition in the lungs of chronic obstructive pulmonary disease patients. Inhal Toxicol 2002;14: 705-720.

-59 Giangreco A, Groot KR, Janes SM: Lung cancer and lung stem cells: strange bedfellows? Am J Respir Crit Care Med 2007; 175:547553.

60 Dovey JS, Zacharek SJ, Kim CF, Lees JA: Bmil is critical for lung tumorigenesis and bronchioalveolar stem cell expansion. Proc Natl Acad Sci USA 2008; 105:11857-11862.

-61 Kim CF, Jackson EL, Woolfenden AE, Lawrence S, Babar I, Vogel S, Crowley D, Bronson RT, Jacks T: Identification of bronchioalveolar stem cells in normal lung and lung cancer. Cell 2005;121:823-835.

62 Kim CF: Paving the road for lung stem cell biology: bronchioalveolar stem cells and other putative distal lung stem cells. Am J Physiol Lung Cell Mol Physiol 2007; 293:L1092-L1098.

-63 Regala RP, Davis RK, Kunz A, Khoor A, Leitges M, Fields AP: Atypical protein kinase $\mathrm{C}\{$ iota $\}$ is required for bronchioalveolar stem cell expansion and lung tumorigenesis. Cancer Res 2009;69:7603-7611.

- 64 Pierrou S, Broberg P, O'Donnell RA, Pawlowski K, Virtala R, Lindqvist E, Richter A, Wilson SJ, Angco G, Moller S, Bergstrand H, Koopmann W, Wieslander E, Stromstedt PE, Holgate ST, Davies DE, Lund J, Djukanovic $\mathrm{R}$ : Expression of genes involved in oxidative stress responses in airway epithelial cells of smokers with chronic obstructive pulmonary disease. Am J Respir Crit Care Med 2007; 175:577-586.

-65 Spira A, Beane J, Pinto-Plata V, Kadar A, Liu G, Shah V, Celli B, Brody JS: Gene expression profiling of human lung tissue from smokers with severe emphysema. Am J Respir Cell Mol Biol 2004;31:601-610.

-66 Spira A, Beane JE, Shah V, Steiling K, Liu G, Schembri F, Gilman S, Dumas YM, Calner P,
Sebastiani P, Sridhar S, Beamis J, Lamb C, Anderson T, Gerry N, Keane J, Lenburg ME, Brody JS: Airway epithelial gene expression in the diagnostic evaluation of smokers with suspect lung cancer. Nat Med 2007;13:361-366.

67 Steiling K, Kadar AY, Bergerat A, Flanigon J, Sridhar S, Shah V, Ahmad QR, Brody JS, Lenburg ME, Steffen M, Spira A: Comparison of proteomic and transcriptomic profiles in the bronchial airway epithelium of current and never smokers. PLoS One 2009; 4:e5043.

68 Beane J, Sebastiani P, Liu G, Brody JS, Lenburg ME, Spira A: Reversible and permanent effects of tobacco smoke exposure on airway epithelial gene expression. Genome Biol 2007;8:R201.

69 Spira A, Beane J, Shah V, Liu G, Schembri F, Yang X, Palma J, Brody JS: Effects of cigarette smoke on the human airway epithelial cell transcriptome. Proc Natl Acad Sci USA 2004;101:10143-10148.

70 Fukumoto S, Yamauchi N, Moriguchi H, Hippo Y, Watanabe A, Shibahara J, Taniguchi $\mathrm{H}$, Ishikawa $\mathrm{S}$, Ito $\mathrm{H}$, Yamamoto $\mathrm{S}$, Iwanari $\mathrm{H}$, Hironaka $\mathrm{M}$, Ishikawa $\mathrm{Y}$, Niki T, Sohara Y, Kodama T, Nishimura M, Fukayama M, Dosaka-Akita H, Aburatani H: Overexpression of the aldo-keto reductase family protein AKR1B10 is highly correlated with smokers' non-small cell lung carcinomas. Clin Cancer Res 2005;11:1776-1785.

71 Beane J, Sebastiani P, Whitfield TH, Steiling K, Dumas YM, Lenburg ME, Spira A: A prediction model for lung cancer diagnosis that integrates genomic and clinical features. Cancer Prev Res (Phila) 2008;1:56-64.

72 Lacroix L, Commo F, Soria JC: Gene expression profiling of non-small-cell lung cancer. Expert Rev Mol Diagn 2008;8:167-178.

73 Pleasance ED, Stephens PJ, O'Meara S, McBride DJ, Meynert A, Jones D, Lin ML, Beare D, Lau KW, Greenman C, Varela I, Nik-Zainal S, Davies HR, Ordonez GR, Mudie LJ, Latimer C, Edkins S, Stebbings L, Chen L, Jia M, Leroy C, Marshall J, Menzies A, Butler A, Teague JW, Mangion J, Sun YA, McLaughlin SF, Peckham HE, Tsung EF, Costa GL, Lee CC, Minna JD, Gazdar A, Birney E, Rhodes MD, McKernan KJ, Stratton MR, Futreal PA, Campbell PJ: A small-cell lung cancer genome with complex signatures of tobacco exposure. Nature 2010;463:184-190.

74 Pleasance ED, Cheetham RK, Stephens PJ, McBride DJ, Humphray SJ, Greenman CD, Varela I, Lin ML, Ordonez GR, Bignell GR, Ye K, Alipaz J, Bauer MJ, Beare D, Butler A, Carter RJ, Chen L, Cox AJ, Edkins S, KokkoGonzales PI, Gormley NA, Grocock RJ, Haudenschild CD, Hims MM, James T, Jia M, Kingsbury Z, Leroy C, Marshall J, Menzies A, Mudie LJ, Ning Z, Royce T, SchulzTrieglaff OB, Spiridou A, Stebbings LA, Szajkowski L, Teague J, Williamson D, Chin L, Ross MT, Campbell PJ, Bentley DR, Futreal
PA, Stratton MR: A comprehensive catalogue of somatic mutations from a human cancer genome. Nature 2010;463:191-196.

75 Goto Y, Shinjo K, Kondo Y, Shen L, Toyota M, Suzuki H, Gao W, An B, Fujii M, Murakami H, Osada H, Taniguchi T, Usami N, Kondo M, Hasegawa Y, Shimokata K, Matsuo K, Hida T, Fujimoto N, Kishimoto T, Issa JP, Sekido Y: Epigenetic profiles distinguish malignant pleural mesothelioma from lung adenocarcinoma. Cancer Res 2009;69:90739082.

76 Landi MT, Zhao Y, Rotunno M, Koshiol J, Liu H, Bergen AW, Rubagotti M, Goldstein AM, Linnoila I, Marincola FM, Tucker MA, Bertazzi PA, Pesatori AC, Caporaso NE, McShane LM, Wang E: MicroRNA expression differentiates histology and predicts survival of lung cancer. Clin Cancer Res 2010;16:430-441.

77 Sato M, Shames DS, Gazdar AF, Minna JD: A translational view of the molecular pathogenesis of lung cancer. J Thorac Oncol 2007; 2:327-343.

78 Molfino NA, Coyle AJ: Gene-environment interactions in chronic obstructive pulmonary disease. Int J Chron Obstruct Pulmon Dis 2008;3:491-497.

79 Patel BD, Coxson HO, Pillai SG, Agusti AG, Calverley PM, Donner CF, Make BJ, Muller NL, Rennard SI, Vestbo J, Wouters EF, Hiorns MP, Nakano Y, Camp PG, Nasute Fauerbach PV, Screaton NJ, Campbell EJ, Anderson WH, Pare PD, Levy RD, Lake SL, Silverman EK, Lomas DA: Airway wall thickening and emphysema show independent familial aggregation in chronic obstructive pulmonary disease. Am J Respir Crit Care Med 2008;178:500-505.

80 Etzel CJ, Amos CI, Spitz MR: Risk for smoking-related cancer among relatives of lung cancer patients. Cancer Res 2003;63:85318535.

81 Cote ML, Kardia SL, Wenzlaff AS, Ruckdeschel JC, Schwartz AG: Risk of lung cancer among white and black relatives of individuals with early-onset lung cancer. JAMA 2005;293:3036-3042.

82 Bailey-Wilson JE, Amos CI, Pinney SM, Petersen GM, de AM, Wiest JS, Fain P, Schwartz AG, You M, Franklin W, Klein C, Gazdar A, Rothschild H, Mandal D, Coons T, Slusser J, Lee J, Gaba C, Kupert E, Perez A, Zhou X, Zeng D, Liu Q, Zhang Q, Seminara D, Minna J, Anderson MW: A major lung cancer susceptibility locus maps to chromosome 6q2325. Am J Hum Genet 2004;75:460-474.

-83 Schwartz AG, Ruckdeschel JC: Familial lung cancer: genetic susceptibility and relationship to chronic obstructive pulmonary disease. Am J Respir Crit Care Med 2006;173: $16-22$.

84 Spitz MR, Wei Q, Dong Q, Amos CI, Wu X: Genetic susceptibility to lung cancer: the role of DNA damage and repair. Cancer Epidemiol Biomarkers Prev 2003;12:689-698. 
-85 Gresner P, Gromadzinska J, Wasowicz W: Polymorphism of selected enzymes involved in detoxification and biotransformation in relation to lung cancer. Lung Cancer 2007;57: $1-25$.

-86 Rotunno M, Yu K, Lubin JH, Consonni D, Pesatori AC, Goldstein AM, Goldin LR, Wacholder S, Welch R, Burdette L, Chanock SJ, Bertazzi PA, Tucker MA, Caporaso NE, Chatterjee N, Bergen AW, Landi MT: Phase I metabolic genes and risk of lung cancer: multiple polymorphisms and mRNA expression. PLoS One 2009;4:e5652.

87 Zhang JY, Wang Y, Prakash C: Xenobioticmetabolizing enzymes in human lung. Curr Drug Metab 2006;7:939-948.

-88 Caramori G, Adcock I: Gene-environment interactions in the development of chronic obstructive pulmonary disease. Curr Opin Allergy Clin Immunol 2006;6:323-328.

89 Cheng SL, Yu CJ, Yang PC: Genetic polymorphisms of cytochrome p450 and matrix metalloproteinase in chronic obstructive pulmonary disease. Biochem Genet 2009;47: 591-601.

-90 Dialyna IA, Miyakis S, Georgatou N, Spandidos DA: Genetic polymorphisms of CYP1A1, GSTM1 and GSTT1 genes and lung cancer risk. Oncol Rep 2003;10:1829-1835.

$91 \mathrm{Hu}$ G, Shi Z, Hu J, Zou G, Peng G, Ran P: Association between polymorphisms of microsomal epoxide hydrolase and COPD: results from meta-analyses. Respirology 2008; 13 : 837-850.

-92 Lee J, Nordestgaard BG, Dahl M: EPHX1 polymorphisms, COPD and asthma in 47,000 individuals and in meta-analysis. Eur Respir J 2011;37:18-25.

93 Kikuchi A, Yamaya M, Suzuki S, Yasuda H, Kubo H, Nakayama K, Handa M, Sasaki T, Shibahara S, Sekizawa K, Sasaki H: Association of susceptibility to the development of lung adenocarcinoma with the heme oxygenase-1 gene promoter polymorphism. Hum Genet 2005;116:354-360.

94 Fu WP, Sun C, Dai LM, Yang LF, Zhang YP: Relationship between COPD and polymorphisms of HOX-1 and mEPH in a Chinese population. Oncol Rep 2007;17:483-488.

$\$ 95$ Calikoglu M, Tamer L, Ates AN, Karakas S, Ercan B: The association between polymorphic genotypes of glutathione S-transferases and COPD in the Turkish population. Biochem Genet 2006;44:307-319.

\$6 Kim WJ, Hoffman E, Reilly J, Hersh C, Demeo D, Washko G, Silverman EK: Association of COPD candidate genes with computed tomography emphysema and airway phenotypes in severe COPD. Eur Respir J 2011; 37:39-43.

-97 Young RP, Whittington CF, Hopkins RJ, Hay BA, Epton MJ, Black PN, Gamble GD: Chromosome $4 \mathrm{q} 31$ locus in COPD is also associated with lung cancer. Eur Respir J 2010;36: 1375-1382.
98 Shibata T, Ohta T, Tong KI, Kokubu A, Odogawa R, Tsuta K, Asamura H, Yamamoto M, Hirohashi S: Cancer related mutations in NRF2 impair its recognition by Keap1-Cul3 E3 ligase and promote malignancy. Proc Natl Acad Sci USA 2008; 105: 13568-13573.

-99 Singh A, Misra V, Thimmulappa RK, Lee H, Ames S, Hoque MO, Herman JG, Baylin SB, Sidransky D, Gabrielson E, Brock MV, Biswal S: Dysfunctional KEAP1-NRF2 interaction in non-small-cell lung cancer. PLoS Med 2006;3:e420.

100 Ohta T, Iijima K, Miyamoto M, Nakahara I, Tanaka H, Ohtsuji M, Suzuki T, Kobayashi A, Yokota J, Sakiyama T, Shibata T, Yamamoto M, Hirohashi S: Loss of Keap1 function activates $\mathrm{Nrf} 2$ and provides advantages for lung cancer cell growth. Cancer Res 2008;68:1303-1309.

101 Padmanabhan B, Tong KI, Ohta T, Nakamura Y, Scharlock M, Ohtsuji M, Kang MI, Kobayashi A, Yokoyama S, Yamamoto M: Structural basis for defects of Keapl activity provoked by its point mutations in lung cancer. Mol Cell 2006;21:689-700.

102 Rangasamy T, Cho CY, Thimmulappa RK, Zhen L, Srisuma SS, Kensler TW, Yamamoto M, Petrache I, Tuder RM, Biswal S: Genetic ablation of Nrf2 enhances susceptibility to cigarette smoke-induced emphysema in mice. J Clin Invest 2004;114:1248-1259.

103 Goven D, Boutten A, Lecon-Malas V, Marchal-Somme J, Amara N, Crestani B, Fournier M, Leseche G, Soler P, Boczkowski J, Bonay M: Altered Nrf2/Keap1-Bach1 equilibrium in pulmonary emphysema. Thorax 2008;63:916-924.

104 Malhotra D, Thimmulappa R, Navas-Acien A, Sandford A, Elliott M, Singh A, Chen L, Zhuang X, Hogg J, Pare P, Tuder RM, Biswal S: Decline in NRF2-regulated antioxidants in chronic obstructive pulmonary disease lungs due to loss of its positive regulator, DJ-1. Am J Respir Crit Care Med 2008; 178:592-604.

105 Suzuki M, Betsuyaku T, Ito Y, Nagai K, Nasuhara Y, Kaga K, Kondo S, Nishimura M: Down-regulated NF-E2-related factor 2 in pulmonary macrophages of aged smokers and patients with chronic obstructive pulmonary disease. Am J Respir Cell Mol Biol 2008;39:673-682.

106 Amos CI, Wu X, Broderick P, Gorlov IP, Gu J, Eisen T, Dong Q, Zhang Q, Gu X, Vijayakrishnan J, Sullivan K, Matakidou A, Wang Y, Mills G, Doheny K, Tsai YY, Chen WV, Shete S, Spitz MR, Houlston RS: Genome-wide association scan of tag SNPs identifies a susceptibility locus for lung cancer at $15 q 25.1$. Nat Genet 2008;40:616622.
07 Falvella FS, Galvan A, Colombo F, Frullanti E, Pastorino U, Dragani TA: Promoter polymorphisms and transcript levels of nicotinic receptor CHRNA5. J Natl Cancer Inst 2010;102:1366-1370.

108 Thorgeirsson TE, Geller F, Sulem P, Rafnar T, Wiste A, Magnusson KP, Manolescu A, Thorleifsson G, Stefansson H, Ingason A, Stacey SN, Bergthorsson JT, Thorlacius S, Gudmundsson J, Jonsson T, Jakobsdottir M, Saemundsdottir J, Olafsdottir O, Gudmundsson LJ, Bjornsdottir G, Kristjansson K, Skuladottir H, Isaksson HJ, Gudbjartsson T, Jones GT, Mueller T, Gottsater A, Flex A, Aben KK, de Vegt F, Mulders PF, Isla D, Vidal MJ, Asin L, Saez B, Murillo L, Blondal T, Kolbeinsson H, Stefansson JG, Hansdottir I, Runarsdottir V, Pola R, Lindblad B, van Rij AM, Dieplinger B, Haltmayer M, Mayordomo JI, Kiemeney LA, Matthiasson SE, Oskarsson $\mathrm{H}$, Tyrfingsson T, Gudbjartsson DF, Gulcher JR, Jonsson S, Thorsteinsdottir U, Kong A, Stefansson K: A variant associated with nicotine dependence, lung cancer and peripheral arterial disease. Nature 2008;452:638-642.

109 Hung RJ, McKay JD, Gaborieau V, Boffetta P, Hashibe M, Zaridze D, Mukeria A, Szeszenia-Dabrowska N, Lissowska J, Rudnai P, Fabianova E, Mates D, Bencko V, Foretova L, Janout V, Chen C, Goodman G, Field JK, Liloglou T, Xinarianos G, Cassidy A, McLaughlin J, Liu G, Narod S, Krokan HE, Skorpen F, Elvestad MB, Hveem K, Vatten L, Linseisen J, Clavel-Chapelon F, Vineis P, Bueno-de-Mesquita HB, Lund E, Martinez C, Bingham S, Rasmuson T, Hainaut P, Riboli E, Ahrens W, Benhamou S, Lagiou P, Trichopoulos D, Holcatova I, Merletti F, Kjaerheim K, Agudo A, Macfarlane G, Talamini R, Simonato L, Lowry R, Conway DI, Znaor A, Healy C, Zelenika D, Boland A, Delepine M, Foglio M, Lechner D, Matsuda F, Blanche H, Gut I, Heath S, Lathrop M, Brennan P: A susceptibility locus for lung cancer maps to nicotinic acetylcholine receptor subunit genes on $15 \mathrm{q} 25$. Nature 2008;452:633-637.

110 Liu P, Vikis HG, Wang D, Lu Y, Wang Y, Schwartz AG, Pinney SM, Yang P, de Andrade M, Petersen GM, Wiest JS, Fain PR, Gazdar A, Gaba C, Rothschild H, Mandal D, Coons T, Lee J, Kupert E, Seminara D, Minna J, Bailey-Wilson JE, Wu X, Spitz MR, Eisen T, Houlston RS, Amos CI, Anderson MW, You M: Familial aggregation of common sequence variants on 15q2425.1 in lung cancer. J Natl Cancer Inst 2008; 100:1326-1330

111 Wu C, Hu Z, Yu D, Huang L, Jin G, Liang J, Guo H, Tan W, Zhang M, Qian J, Lu D, Wu T, Lin D, Shen H: Genetic variants on chromosome 15 q25 associated with lung cancer risk in Chinese populations. Cancer Res 2009;69:5065-5072. 
112 Song JY, Lim JW, Kim H, Kim KH: Role of 122 Downs JA, Jackson SP: A means to a DNA $\mathrm{NF}-\mathrm{kappaB}$ and DNA repair protein $\mathrm{Ku}$ on apoptosis in pancreatic acinar cells. Ann NY Acad Sci 2003;1010:259-263.

113 Song JY, Lim JW, Kim H, Morio T, Kim KH: Oxidative stress induces nuclear loss of DNA repair proteins Ku70 and Ku80 and apoptosis in pancreatic acinar AR42J cells. J Biol Chem 2003;278:36676-36687.

$>114$ Pieper MP, Chaudhary NI, Park JE: Acetylcholine-induced proliferation of fibroblasts and myofibroblasts in vitro is inhibited by tiotropium bromide. Life Sci 2007;80:22702273.

115 Carlisle DL, Liu X, Hopkins TM, Swick MC, Dhir R, Siegfried JM: Nicotine activates cell-signaling pathways through muscletype and neuronal nicotinic acetylcholine receptors in non-small cell lung cancer cells. Pulm Pharmacol Ther 2007;20:629641.

-116 Saccone NL, Wang JC, Breslau N, Johnson EO, Hatsukami D, Saccone SF, Grucza RA, Sun L, Duan W, Budde J, Culverhouse RC, Fox L, Hinrichs AL, Steinbach JH, Wu M, Rice JP, Goate AM, Bierut LJ: The CHRNA5-CHRNA3-CHRNB4 nicotinic receptor subunit gene cluster affects risk for nicotine dependence in African-Americans and in European-Americans. Cancer Res 2009;69:6848-6856.

- 117 Lips EH, Gaborieau V, McKay JD, Chabrier A, Hung RJ, Boffetta P, Hashibe M, Zaridze D, Szeszenia-Dabrowska N, Lissowska J, Rudnai P, Fabianova E, Mates D, Bencko V, Foretova L, Janout V, Field JK, Liloglou T, Xinarianos G, McLaughlin J, Liu G, Skorpen F, Elvestad MB, Hveem K, Vatten L, Study E, Benhamou S, Lagiou P, Holcatova I, Merletti F, Kjaerheim K, Agudo A, Castellsague X, Macfarlane TV, Barzan L, Canova C, Lowry R, Conway DI, Znaor A, Healy C, Curado MP, Koifman S, Eluf-Neto J, Matos E, Menezes A, Fernandez L, Metspalu A, Heath S, Lathrop M, Brennan P: Association between a 15q25 gene variant, smoking quantity and tobacco-related cancers among 17000 individuals. Int J Epidemiol 2010;39:563-577.

- 118 Anderson GP, Bozinovski S: Acquired somatic mutations in the molecular pathogenesis of COPD. Trends Pharmacol Sci 2003;24:71-76.

- 119 Sancar A, Lindsey-Boltz LA, Unsal-Kacmaz K, Linn S: Molecular mechanisms of mammalian DNA repair and the DNA damage checkpoints. Annu Rev Biochem 2004;73:39-85.

-120 Meek K, Gupta S, Ramsden DA, Lees-Miller SP: The DNA-dependent protein kinase: the director at the end. Immunol Rev 2004;200:132-141.

>121 Meek K, Dang V, Lees-Miller SP: DNA-PK: the means to justify the ends? Adv Immunol 2008;99:33-58. end: the many roles of Ku. Nat Rev Mol Cell Biol 2004;5:367-378.

123 Caramori G, Papi A: Pathogenic link between chronic obstructive pulmonary disease and squamous cell lung cancer. Expert Rev Respir Med 2007;1:171-175.

124 Brody JS, Spira A: State of the art. Chronic obstructive pulmonary disease, inflammation, and lung cancer. Proc Am Thorac Soc 2006;3:535-537.

125 Popanda O, Schattenberg T, Phong CT, Butkiewicz D, Risch A, Edler L, Kayser K, Dienemann H, Schulz V, Drings P, Bartsch H, Schmezer P: Specific combinations of DNA repair gene variants and increased risk for non-small cell lung cancer. Carcinogenesis 2004;25:2433-2441.

126 Wei Q, Cheng L, Amos CI, Wang LE, Guo Z, Hong WK, Spitz MR: Repair of tobacco carcinogen-induced DNA adducts and lung cancer risk: a molecular epidemiologic study. J Natl Cancer Inst 2000;92:1764-1772.

127 Gehring M, Reik W, Henikoff S: DNA demethylation by DNA repair. Trends Genet 2009;25:82-90.

128 Miller KM, Tjeertes JV, Coates J, Legube G, Polo SE, Britton S, Jackson SP: Human HDAC1 and HDAC2 function in the DNAdamage response to promote DNA nonhomologous end-joining. Nat Struct Mol Biol 2010;17:1144-1151.

129 Vempati RK, Jayani RS, Notani D, Sengupta A, Galande S, Haldar D: p300-mediated acetylation of histone $\mathrm{H} 3$ lysine 56 functions in DNA damage response in mammals. J Biol Chem 2010;285:28553-28564.

130 Yuan Z, Zhang X, Sengupta N, Lane WS, Seto E: SIRT1 regulates the function of the Nijmegen breakage syndrome protein. Mol Cell 2007;27:149-162.

131 Ito K, Ito M, Elliott WM, Cosio B, Caramori G, Kon OM, Barczyk A, Hayashi S, Adcock IM, Hogg JC, Barnes PJ: Decreased histone deacetylase activity in chronic obstructive pulmonary disease. N Engl J Med 2005;352:1967-1976. J, Kharitonov S, Goto H, Bemis JE, Elliott P, Barnes PJ, Ito K: A protein deacetylase SIRT1 is a negative regulator of metalloproteinase-9. FASEB J 2009;23:2810-2819.

133 Rajendrasozhan S, Yang SR, Kinnula VL, Rahman I: SIRT1, an antiinflammatory and antiaging protein, is decreased in lungs of patients with chronic obstructive pulmonary disease. Am J Respir Crit Care Med 2008; 177:861-870.

134 Tuder RM, Yun JH, Graham BB: Cigarette smoke triggers code red: p21CIP1/WAF1/ SDI1 switches on danger responses in the lung. Am J Respir Cell Mol Biol 2008;39:1-6.
-132 Nakamaru Y, Vuppusetty C, Wada H, Milne JC, Ito M, Rossios C, Elliot M, Hogg
135 Hwang SJ, Cheng LS, Lozano G, Amos CI, $\mathrm{Gu}$ X, Strong LC: Lung cancer risk in germline p53 mutation carriers: association between an inherited cancer predisposition, cigarette smoking, and cancer risk. Hum Genet 2003;113:238-243.

136 Arif E, Vibhuti A, Deepak D, Singh B, Siddiqui MS, Pasha MA: COX2 and p53 riskalleles coexist in COPD. Clin Chim Acta 2008;397:48-50.

137 Lee YL, Chen W, Tsai WK, Lee JC, Chiou HL, Shih CM, Wang YC: Polymorphisms of p53 and p21 genes in chronic obstructive pulmonary disease. J Lab Clin Med 2006; 147:228-233.

138 Tomita K, Caramori G, Lim S, Ito K, Hanazawa T, Oates T, Chiselita I, Jazrawi E, Chung KF, Barnes PJ, Adcock IM: Increased p21(CIP1/WAF1) and B cell lymphoma leukemia-x(L) expression and reduced apoptosis in alveolar macrophages from smokers. Am J Respir Crit Care Med 2002;166:724-731.

139 Tsuji T, Aoshiba K, Nagai A: Alveolar cell senescence in patients with pulmonary emphysema. Am J Respir Crit Care Med 2006; 174:886-893.

140 Tsuji T, Aoshiba K, Nagai A: Alveolar cell senescence exacerbates pulmonary inflammation in patients with chronic obstructive pulmonary disease. Respiration 2010;80:59-70.

-141 Belinsky SA, Palmisano WA, Gilliland FD, Crooks LA, Divine KK, Winters SA, Grimes MJ, Harms HJ, Tellez CS, Smith TM, Moots PP, Lechner JF, Stidley CA, Crowell RE: Aberrant promoter methylation in bronchial epithelium and sputum from current and former smokers. Cancer Res 2002;62:23702377.

142 Russo AL, Thiagalingam A, Pan H, Califano J, Cheng KH, Ponte JF, Chinnappan D, Nemani P, Sidransky D, Thiagalingam S: Differential DNA hypermethylation of critical genes mediates the stage-specific tobacco smoke-induced neoplastic progression of lung cancer. Clin Cancer Res 2005; 11:2466-2470.

143 Soria JC, Rodriguez M, Liu DD, Lee JJ, Hong WK, Mao L: Aberrant promoter methylation of multiple genes in bronchial brush samples from former cigarette smokers. Cancer Res 2002;62:351-355.

144 Ocak S, Sos ML, Thomas RK, Massion PP: High-throughput molecular analysis in lung cancer: insights into biology and potential clinical applications. Eur Respir J 2009;34:489-506.

145 Guil S, Esteller M: DNA methylomes, histone codes and miRNAs: tying it all together. Int J Biochem Cell Biol 2009;41:87-95.

146 Dubey S, Powell CA: Update in lung cancer 2008. Am J Respir Crit Care Med 2009;179: 860-868.

147 Esteller M: Epigenetics in cancer. N Engl J Med 2008;358:1148-1159. 
148 Irizarry RA, Ladd-Acosta C, Wen B, Wu Z, Montano C, Onyango P, Cui H, Gabo K, Rongione M, Webster M, Ji H, Potash JB, Sabunciyan S, Feinberg AP: The human colon cancer methylome shows similar hypoand hypermethylation at conserved tissuespecific CpG island shores. Nat Genet 2009; 41:178-186.

149 Adcock IM, Ford P, Barnes PJ, Ito K: Epigenetics and airways disease. Respir Res 2006;7:21.

150 Rauch TA, Zhong X, Wu X, Wang M, Kernstine $\mathrm{KH}$, Wang Z, Riggs AD, Pfeifer GP: High-resolution mapping of DNA hypermethylation and hypomethylation in lung cancer. Proc Natl Acad Sci USA 2008;105: 252-257.

- 151 Palmisano WA, Divine KK, Saccomanno G, Gilliland FD, Baylin SB, Herman JG, Belinsky SA: Predicting lung cancer by detecting aberrant promoter methylation in sputum. Cancer Res 2000;60:5954-5958.

-152 Belinsky SA, Nikula KJ, Palmisano WA, Michels R, Saccomanno G, Gabrielson E, Baylin SB, Herman JG: Aberrant methylation of p16(INK4a) is an early event in lung cancer and a potential biomarker for early diagnosis. Proc Natl Acad Sci USA 1998;95: 11891-11896.

-153 Brock MV, Hooker CM, Ota-Machida E, Han Y, Guo M, Ames S, Glockner S, Piantadosi S, Gabrielson E, Pridham G, Pelosky K, Belinsky SA, Yang SC, Baylin SB, Herman JG: DNA methylation markers and early recurrence in stage I lung cancer. N Engl J Med 2008;358:1118-1128.

-154 Lai JC, Wu JY, Cheng YW, Yeh KT, Wu TC, Chen CY, Lee H: O6-Methylguanine-DNA methyltransferase hypermethylation modulated by 17beta-estradiol in lung cancer cells. Anticancer Res 2009;29:2535-2540.

- 155 Liu F, Killian JK, Yang M, Walker RL, Hong JA, Zhang M, Davis S, Zhang Y, Hussain M, Xi S, Rao M, Meltzer PA, Schrump DS: Epigenomic alterations and gene expression profiles in respiratory epithelia exposed to cigarette smoke condensate. Oncogene 2010;29:3650-3664.

-156 Hu Z, Chen J, Tian T, Zhou X, Gu H, Xu L, Zeng Y, Miao R, Jin G, Ma H, Chen Y, Shen $\mathrm{H}$ : Genetic variants of miRNA sequences and non-small cell lung cancer survival. J Clin Invest 2008;118:2600-2608.

-157 Tian T, Shu Y, Chen J, Hu Z, Xu L, Jin G, Liang J, Liu P, Zhou X, Miao R, Ma H, Chen $\mathrm{Y}$, Shen $\mathrm{H}$ : A functional genetic variant in microRNA-196a2 is associated with increased susceptibility of lung cancer in Chinese. Cancer Epidemiol Biomarkers Prev 2009;18:1183-1187.
158 Schembri F, Sridhar S, Perdomo C, Gustafson AM, Zhang X, Ergun A, Lu J, Liu G, Zhang X, Bowers J, Vaziri C, Ott K, Sensinger K, Collins JJ, Brody JS, Getts R, Lenburg ME, Spira A: MicroRNAs as modulators of smoking-induced gene expression changes in human airway epithelium. Proc Natl Acad Sci USA 2009;106:2319-2324.

159 Van Pottelberge GR, Mestdagh P, Bracke KR, Thas O, van Durme YM, Joos GF, Vandesompele J, Brusselle GG: MicroRNA Expression in induced sputum of smokers and patients with chronic obstructive pulmonary disease. Am J Respir Crit Care Med 2010, E-pub ahead of print.

160 Sato T, Liu X, Nelson A, Nakanishi M, Kanaji N, Wang X, Kim M, Li Y, Sun J, Michalski J, Patil A, Basma H, Holz O, Magnussen H, Rennard SI: Reduced miR-146a increases prostaglandin Ein chronic obstructive pulmonary disease fibroblasts. Am J Respir Crit Care Med 2010;182:1020-1029.

161 Balkwill F, Mantovani A: Inflammation and cancer: back to Virchow? Lancet 2001; 357:539-545.

162 Balkwill F, Mantovani A: Cancer and inflammation: implications for pharmacology and therapeutics. Clin Pharmacol Ther 2010;87:401-406.

163 Reiman JM, Kmieciak M, Manjili MH, Knutson KL: Tumor immunoediting and immunosculpting pathways to cancer progression. Semin Cancer Biol 2007; 17:275287.

164 Otsuka S, Bebb G: The CXCR4/SDF-1 chemokine receptor axis: a new target therapeutic for non-small cell lung cancer. J Thorac Oncol 2008;3:1379-1383.

165 Tauler J, Mulshine JL: Lung cancer and inflammation: interaction of chemokines and hnRNPs. Curr Opin Pharmacol 2009; 9:384-388.

166 Pan H, Luo C, Li R, Qiao A, Zhang L, Mines M, Nyanda AM, Zhang J, Fan GH: Cyclophilin A is required for CXCR4-mediated nuclear export of heterogeneous nuclear ribonucleoprotein A2, activation and nuclear translocation of ERK1/2, and chemotactic cell migration. J Biol Chem 2008;283: 623-637.

167 Katsimpoula S, Patrinou-Georgoula M, Makrilia N, Dimakou K, Guialis A, Orfanidou D, Syrigos KN: Overexpression of hnRNPA2/B1 in bronchoscopic specimens: a potential early detection marker in lung cancer. Anticancer Res 2009;29:1373-1382.

168 Sueoka E, Sueoka N, Iwanaga K, Sato A, Suga K, Hayashi S, Nagasawa K, Nakachi K: Detection of plasma hnRNP B1 mRNA, a new cancer biomarker, in lung cancer patients by quantitative real-time polymerase chain reaction. Lung Cancer 2005;48:7783.
169 Chen Y, Chen P, Hanaoka M, Droma Y, Kubo K: Enhanced levels of prostaglandin E2 and matrix metalloproteinase-2 correlate with the severity of airflow limitation in stable COPD. Respirology 2008;13:10141021.

170 Xaubet A, Roca-Ferrer J, Pujols L, Ramirez J, Mullol J, Marin-Arguedas A, Torrego A, Gimferrer JM, Picado C: Cyclooxygenase-2 is up-regulated in lung parenchyma of chronic obstructive pulmonary disease and down-regulated in idiopathic pulmonary fibrosis. Sarcoidosis Vasc Diffuse Lung Dis 2004;21:35-42.

- 171 Slatore CG, Au DH, Littman AJ, Satia JA, White E: Association of nonsteroidal antiinflammatory drugs with lung cancer: results from a large cohort study. Cancer Epidemiol Biomarkers Prev 2009;18:12031207.

172 Van Dyke AL, Cote ML, Prysak G, Claeys GB, Wenzlaff AS, Schwartz AG: Regular adult aspirin use decreases the risk of nonsmall cell lung cancer among women. Cancer Epidemiol Biomarkers Prev 2008; 17: 148-157.

173 Harris RE: Cyclooxygenase-2 (cox-2) blockade in the chemoprevention of cancers of the colon, breast, prostate, and lung. Inflammopharmacology 2009;17:55-67.

174 Campa D, Zienolddiny S, Maggini V, Skaug V, Haugen A, Canzian F: Association of a common polymorphism in the cyclooxygenase 2 gene with risk of non-small cell lung cancer. Carcinogenesis 2004;25:229235.

175 Karin M: NF-kappaB as a critical link between inflammation and cancer. Cold Spring Harb Perspect Biol 2009; 1:a000141.

176 Caramori G, Adcock IM, Ito K: Anti-inflammatory inhibitors of IkappaB kinase in asthma and COPD. Curr Opin Investig Drugs 2004;5:1141-1147.

177 Di Stefano A, Caramori G, Oates T, Capelli A, Lusuardi M, Gnemmi I, Ioli F, Chung KF, Donner CF, Barnes PJ, Adcock IM: Increased expression of nuclear factor-kap$\mathrm{paB}$ in bronchial biopsies from smokers and patients with COPD. Eur Respir J 2002;20 556-563.

178 Tang X, Liu D, Shishodia S, Ozburn N, Behrens C, Lee JJ, Hong WK, Aggarwal BB, Wistuba II: Nuclear factor-kappaB (NFkappaB) is frequently expressed in lung cancer and preneoplastic lesions. Cancer 2006; 107:2637-2646.

179 Tichelaar JW, Zhang Y, leRiche JC, Biddinger PW, Lam S, Anderson MW: Increased staining for phospho-Akt, p65/ RELA and cIAP-2 in pre-neoplastic human bronchial biopsies. BMC Cancer 2005;5: 155 . 
180 Greten FR, Karin M: The IKK/NF-kappaB 190 Matsuo Y, Amano S, Furuya M, Namiki K, activation pathway - a target for prevention and treatment of cancer. Cancer Lett 2004; 206:193-199.

-181 Takahashi H, Ogata H, Nishigaki R, Broide $\mathrm{DH}$, Karin M: Tobacco smoke promotes lung tumorigenesis by triggering IKKbetaand JNK1-dependent inflammation. Cancer Cell 2010;17:89-97.

182 Levy D, Kuo AJ, Chang Y, Schaefer U, Kitson C, Cheung P, Espejo A, Zee BM, Liu CL, Tangsombatvisit S, Tennen RI, Kuo AY, Tanjing S, Cheung R, Chua KF, Utz PJ, Shi X, Prinjha RK, Lee K, Garcia BA, Bedford MT, Tarakhovsky A, Cheng X, Gozani O: Lysine methylation of the NF-kappaB subunit RelA by SETD6 couples activity of the histone methyltransferase GLP at chromatin to tonic repression of NF-kappaB signaling. Nat Immunol 2011;12:29-36.

183 Adcock IM, Chung KF, Caramori G, Ito K: Kinase inhibitors and airway inflammation. Eur J Pharmacol 2006;533:118-132.

184 Marwick JA, Caramori G, Casolari P, Mazzoni F, Kirkham PA, Adcock IM, Chung KF, Papi A: A role for phosphoinositol 3-kinase delta in the impairment of glucocorticoid responsiveness in patients with chronic obstructive pulmonary disease. J Allergy Clin Immunol 2010;125:1146-1153.

185 Marwick JA, Chung KF, Adcock IM: Phosphatidylinositol 3-kinase isoforms as targets in respiratory disease. Ther Adv Respir Dis 2010;4:19-34.

186 Popkie AP, Zeidner LC, Albrecht AM, D'Ippolito A, Eckardt S, Newsom DE, Groden J, Doble BW, Aronow B, McLaughlin KJ, White P, Phiel CJ: Phosphatidylinositol 3-kinase (PI3K) signaling via glycogen synthase kinase-3 (Gsk-3) regulates DNA methylation of imprinted loci. J Biol Chem 2010;285:41337-41347.

187 Gustafson AM, Soldi R, Anderlind C, Scholand MB, Qian J, Zhang X, Cooper K, Walker D, McWilliams A, Liu G, Szabo E, Brody J, Massion PP, Lenburg ME, Lam S, Bild AH, Spira A: Airway PI3K pathway activation is an early and reversible event in lung cancer development. Sci Transl Med 2010;2:26ra25.

188 Nanjundan M, Byers LA, Carey MS, Siwak DR, Raso MG, Diao L, Wang J, Coombes KR, Roth JA, Mills GB, Wistuba II, Minna JD, Heymach JV: Proteomic profiling identifies pathways dysregulated in non-small cell lung cancer and an inverse association of AMPK and adhesion pathways with recurrence. J Thorac Oncol 2010;5:18941904.

189 Mountzios G, Planchard D, Besse B, Validire P, Girard P, Devisme C, Dimopoulos MA, Soria JC, Fouret P: Mitogen-activated protein kinase activation in lung adenocarcinoma: a comparative study between ever smokers and never smokers. Clin Cancer Res 2008;14:4096-4102. Sakurai K, Nishiyama M, Sudo T, Tatsumi K, Kuriyama T, Kimura S, Kasuya Y: Involvement of p38alpha mitogen-activated protein kinase in lung metastasis of tumor cells. J Biol Chem 2006;281:36767-36775.

191 St Germain C, Niknejad N, Ma L, Garbuio K, Hai T, Dimitroulakos J: Cisplatin induces cytotoxicity through the mitogen-activated protein kinase pathways and activating transcription factor 3. Neoplasia 2010; 12:527-538.

192 Hui L, Bakiri L, Stepniak E, Wagner EF: p38alpha: a suppressor of cell proliferation and tumorigenesis. Cell Cycle 2007;6: 2429-2433.

193 Lai SY, Johnson FM: Defining the role of the JAK-STAT pathway in head and neck and thoracic malignancies: implications for future therapeutic approaches. Drug Resist Updat 2010;13:67-78.

194 He B, You L, Xu Z, Mazieres J, Lee AY, Jablons DM: Activity of the suppressor of cytokine signaling-3 promoter in human non-small-cell lung cancer. Clin Lung Cancer 2004;5:366-370.

195 Huang WL, Yeh HH, Lin CC, Lai WW, Chang JY, Chang WT, Su WC: Signal transducer and activator of transcription 3 activation up-regulates interleukin- 6 autocrine production: a biochemical and genetic study of established cancer cell lines and clinical isolated human cancer cells. Mol Cancer 2010;9:309.

196 Belvisi MG, Mitchell JA: Targeting PPAR receptors in the airway for the treatment of inflammatory lung disease. Br J Pharmacol 2009;158:994-1003.

197 Li MY, Yuan H, Ma LT, Kong AW, Hsin MK, Yip JH, Underwood MJ, Chen GG: Roles of peroxisome proliferator-activated receptor-alpha and -gamma in the development of non-small cell lung cancer. Am J Respir Cell Mol Biol 2010;43:674-683.

198 Ford PA, Durham AL, Russell RE, Gordon F, Adcock IM, Barnes PJ: Treatment effects of low-dose theophylline combined with an inhaled corticosteroid in COPD. Chest 2010;137:1338-1344.

-199 Spange S, Wagner T, Heinzel T, Kramer $\mathrm{OH}$ : Acetylation of non-histone proteins modulates cellular signalling at multiple levels. Int J Biochem Cell Biol 2009;41:185198.

200 Cho HY, Reddy SP, Kleeberger SR: Nrf2 defends the lung from oxidative stress. Antioxid Redox Signal 2006;8:76-87.

201 Valinluck V, Tsai HH, Rogstad DK, Burdzy A, Bird A, Sowers LC: Oxidative damage to methyl-CpG sequences inhibits the binding of the methyl-CpG binding domain (MBD) of methyl-CpG binding protein 2 (MeCP2). Nucleic Acids Res 2004;32:41004108.
202 Cappuzzo F, Ciuleanu T, Stelmakh L, Cicenas S, Szczesna A, Juhasz E, Esteban E, Molinier O, Brugger W, Melezinek I, Klingelschmitt G, Klughammer B, Giaccone G: Erlotinib as maintenance treatment in advanced non-small-cell lung cancer: a multicentre, randomised, placebo-controlled phase 3 study. Lancet Oncol 2010;11:521529.

203 Woodruff PG, Wolff M, Hohlfeld JM, Krug N, Dransfield MT, Sutherland ER, Criner GJ, Kim V, Prasse A, Nivens MC, Tetzlaff K, Heilker R, Fahy JV: Safety and efficacy of an inhaled epidermal growth factor receptor inhibitor (BIBW 2948 BS) in chronic obstructive pulmonary disease. Am J Respir Crit Care Med 2010;181:438-445.

204 Balansky R, Ganchev G, Iltcheva M, Steele VE, De Flora S: Prevention of cigarette smoke-induced lung tumors in mice by budesonide, phenethyl isothiocyanate, and $\mathrm{N}$-acetylcysteine. Int J Cancer 2010;126: 1047-1054.

205 Kiri VA, Fabbri LM, Davis KJ, Soriano JB: Inhaled corticosteroids and risk of lung cancer among COPD patients who quit smoking. Respir Med 2009;103:85-90.

206 van den Berg RM, Teertstra HJ, van Zandwijk N, van Tinteren H, Visser C, Pasic A, Sutedja TG, Baas P, Golding RP, Postmus PE, Smit EF: CT detected indeterminate pulmonary nodules in a chemoprevention trial of fluticasone. Lung Cancer 2008;60:57-61.

207 van den Berg RM, van Tinteren H, van Zandwijk N, Visser C, Pasic A, Kooi C, Sutedja TG, Baas P, Grunberg K, Mooi WJ, Snijders PJ, Postmus PE, Smit EF: The influence of fluticasone inhalation on markers of carcinogenesis in bronchial epithelium. Am J Respir Crit Care Med 2007;175: 1061-1065.

208 Lam S, leRiche JC, McWilliams A, MacAulay C, Dyachkova Y, Szabo E, Mayo J, Schellenberg R, Coldman A, Hawk E, Gazdar A: A randomized phase IIb trial of pulmicort turbuhaler (budesonide) in people with dysplasia of the bronchial epithelium. Clin Cancer Res 2004; 10:6502-6511.

209 Calverley PM, Anderson JA, Celli B, Ferguson GT, Jenkins C, Jones PW, Yates JC, Vestbo J: Salmeterol and fluticasone propionate and survival in chronic obstructive pulmonary disease. N Engl J Med 2007;356: 775-789.

210 Song P, Spindel ER: Basic and clinical aspects of non-neuronal acetylcholine: expression of non-neuronal acetylcholine in lung cancer provides a new target for cancer therapy. J Pharmacol Sci 2008;106:180-185.

211 Song P, Sekhon HS, Fu XW, Maier M, Jia Y, Duan J, Proskosil BJ, Gravett C, Lindstrom J, Mark GP, Saha S, Spindel ER: Activated cholinergic signaling provides a target in squamous cell lung carcinoma. Cancer Res 2008;68:4693-4700. 
212 Tashkin DP, Celli B, Senn S, Burkhart D, Kesten S, Menjoge S, Decramer M: A 4-year trial of tiotropium in chronic obstructive pulmonary disease. N Engl J Med 2008;359: 1543-1554.

213 Lin Y, Bai L, Chen W, Xu S: The NF-kappaB activation pathways, emerging molecular targets for cancer prevention and therapy. Expert Opin Ther Targets 2010;14:45-55.

214 Denlinger CE, Rundall BK, Jones DR: Proteasome inhibition sensitizes non-small cell lung cancer to histone deacetylase inhibitor-induced apoptosis through the generation of reactive oxygen species. J Thorac Cardiovasc Surg 2004;128:740-748.

215 Rundall BK, Denlinger CE, Jones DR: Combined histone deacetylase and NFkappaB inhibition sensitizes non-small cell lung cancer to cell death. Surgery 2004;136: $416-425$.
16 Stathopoulos GT, Sherrill TP, Cheng DS, Scoggins RM, Han W, Polosukhin VV, Connelly L, Yull FE, Fingleton B, Blackwell TS: Epithelial NF-kappaB activation promotes urethane-induced lung carcinogenesis. Proc Natl Acad Sci USA 2007;104: 18514-18519.

217 Komarova EA, Krivokrysenko V, Wang K, Neznanov N, Chernov MV, Komarov PG, Brennan ML, Golovkina TV, Rokhlin OW, Kuprash DV, Nedospasov SA, Hazen SL, Feinstein E, Gudkov AV: p53 is a suppressor of inflammatory response in mice. FASEB J 2005; 19:1030-1032.

218 Lawless MW, O’Byrne KJ, Gray SG: Oxidative stress induced lung cancer and COPD: opportunities for epigenetic therapy. J Cell Mol Med 2009;13:2800-2821.

219 Decramer M, Rutten-van Mölken M, Dekhuijzen PN, Troosters T, van Herwaarden C, Pellegrino R, van Schayck CP, Olivieri D, Del Donna M, De Backer W, Lankhorst I, Ardia A: Effects of N-acetylcysteine on outcomes in chronic obstructive pulmonary disease (Bronchitis Randomized on NAC Cost-Utility Study, BRONCUS): a randomised placebo-controlled trial. Lancet 2005;365:1552-1560.
20 van Zandwijk N, Dalesio O, Pastorino U, de Vries N, van Tinteren H: EUROSCAN, a randomized trial of vitamin $\mathrm{A}$ and $\mathrm{N}$-acetylcysteine in patients with head and neck cancer or lung cancer. For the EUropean Organization for Research and Treatment of Cancer Head and Neck and Lung Cancer Cooperative Groups. J Natl Cancer Inst 2000;92:977-986.

221 Smith RA, Murphy MP: Animal and human studies with the mitochondria-targeted antioxidant MitoQ. Ann NY Acad Sci 2010;1201:96-103.

222 Rahman I, Adcock IM: Oxidative stress and redox regulation of lung inflammation in COPD. Eur Respir J 2006;28:219-242. 